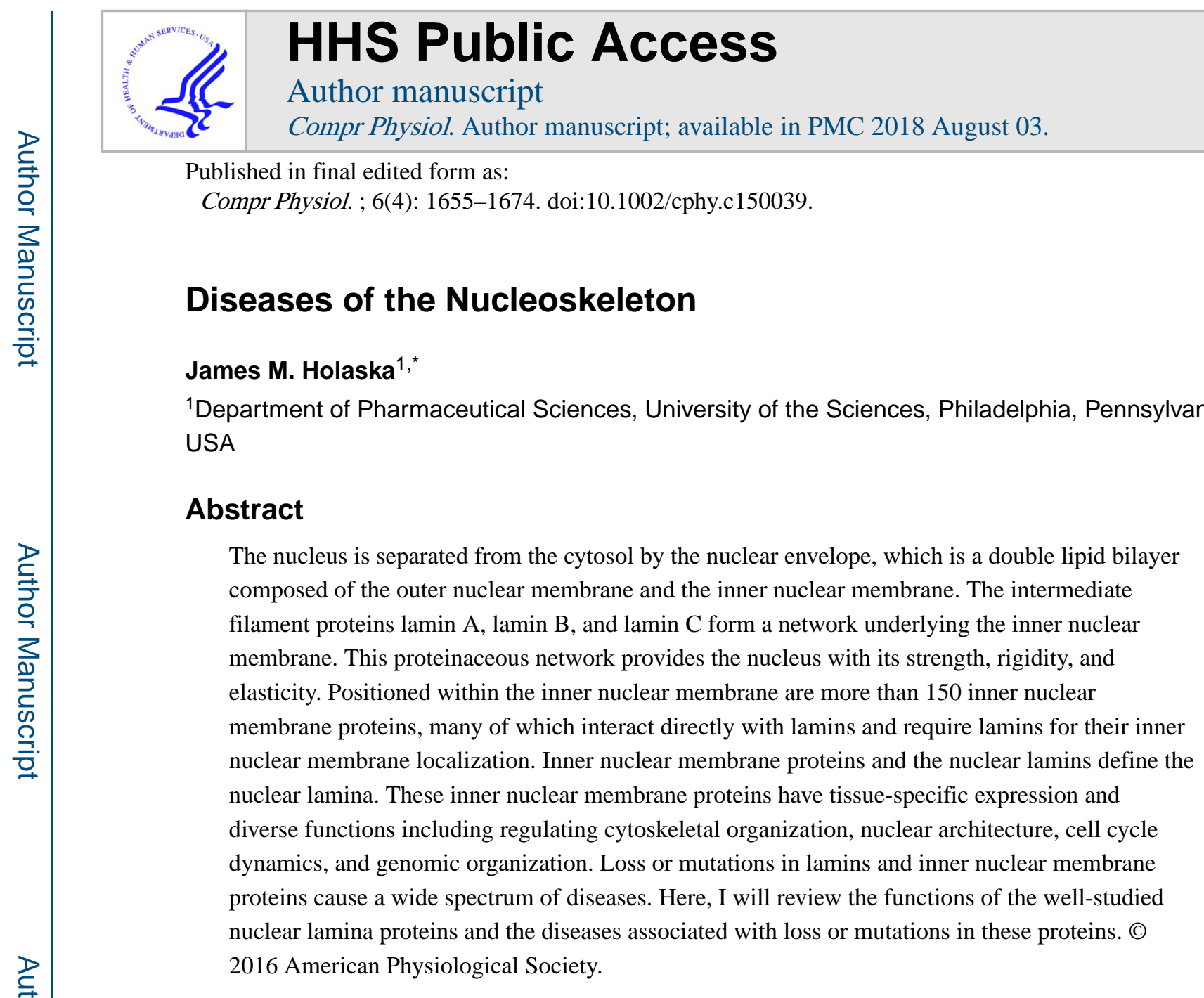

\title{
Introduction
}

The nucleus is separated from the cytosol by the nuclear envelope. The nuclear envelope is a double lipid bilayer composed of the inner nuclear membrane (INM) and the outer nuclear membrane $(\mathrm{ONM})$, which is contiguous with the endoplasmic reticulum $(55,285)$. Large macromolecular complexes called nuclear pore complexes (NPCs) are positioned within the nuclear envelope. NPCs are integral for cellular function as they mediate the bidirectional transport of molecules across the nuclear envelope, including RNA for translation in the cytoplasm and proteins that mediate important nuclear processes (e.g., DNA replication and RNA transcription). The type- $\mathrm{V}$ intermediate filament proteins lamin $\mathrm{A}$, lamin $\mathrm{B}$, and lamin $\mathrm{C}$ form a proteinaceous meshwork at the INM that serves as a scaffold for the nuclear envelope and provides the nucleus with its strength, rigidity and elasticity $(28,42)$. There are over 150 predicted INM proteins (also known as nuclear envelope transmembrane proteins or NETs $(141,269,317)$. The functions of the vast majority of these nuclear envelope proteins remain unknown. Many of the NETs, including the well-studied nuclear envelope proteins lamin B receptor (LBR) emerin, MAN1 and lamina-associated protein 2 (LAP2), bind lamins. The INM proteins and lamins define the nuclear lamina (242). These nuclear envelope proteins show diverse, tissue-specific expression, and have a variety of known

\footnotetext{
`Correspondence to j.holaska@usciences.edu.
} 
functions, including regulating cytoskeletal organization (317), nuclear architecture and dynamics, the cell cycle (140), and genomic organization (332).

Mutations in lamins and nuclear lamina components cause a wide spectrum of diseases (28). Lamin A mutations often cause mislocalization of INM proteins to the endoplasmic reticulum (28). Specific lamin A mutations often result in mislocalization of a subset of INM proteins, depending on the mutation. How individual mutations in nuclear lamina proteins specifically effect the localization of specific INM proteins and how this localization may contribute to the wide spectrum of diseases caused by mutations in lamins and nuclear lamina proteins remains unknown. Some mutations in the gene encoding lamin A also cause clustering of NPCs and impaired nuclear transport (28), suggesting disruption of nuclear transport by selected lamin A mutations may also contribute to the disease phenotype. Mislocalization of INM proteins and NPCs by lamin mutations supports the role of lamins in stably localizing these proteins to the nuclear envelope. Here I will review diseases associated with mutations in the genes encoding nuclear envelope proteins and the function of these nuclear envelope proteins, if known (Table 1).

\section{Nuclear Envelopathies}

\section{Emery-Dreifuss muscular dystrophy}

There are two major types of Emery Dreifuss muscular dystrophy (EDMD): X-linked (XEDMD or EDMD1) and autosomal EDMD (AD-EDMD or EDMD2), which can occur in a dominant or very rare recessive form $(128,247)$. EDMD is characterized by progressive skeletal muscle wasting, contractures of major tendons and cardiac conduction defects (65). The incidence of X-EDMD is estimated at 1 in 100,000. The incidence of AD-EDMD is not known, but it is thought to be more prevalent (108).

Emery and Dreifuss first identified EDMD in the late 1950s and early 1960s as a new form of muscular dystrophy $(59,65,67)$. Almost four decades later, X-EDMD was shown to be caused by mutations in the gene encoding the INM protein emerin (EMD, then known as $S T A ; 14)$. Emerin is a well-conserved, ubiquitously expressed protein of the INM that has diverse functions, including the regulation of gene expression, cell signaling, nuclear structure, and chromatin architecture. Five years later, AD-EDMD was linked to $L M N A$ mutations, which encodes lamins $\mathrm{A}$ and $\mathrm{C}$ (17). The nuclear lamins are type- $\mathrm{V}$ intermediate filament proteins involved in diverse cellular functions, including nuclear architecture, mechanotransduction, gene expression, and chromatin organization (28). EDMD-like syndromes are also caused by mutations in $S Y N E-1$ and $S Y N E-2$ (327), TMEM43(158), and FHL1 (95).

EDMD is characterized by progressive skeletal muscle wasting, contractures of major tendons, and life-threatening irregular heart rhythms (187, 309, 321). EDMD initially presents in the first decade of life (66) with early contractures of major tendons and posterior cervical muscles. Progressive muscle wasting can also be seen early in EDMD, often starting in the humeroperoneal muscles. Cardiac conduction defects, arrhythmia, and cardiomyopathy often accompany these skeletal muscle phenotypes (65). Increased serum creatine kinase levels may also occur $(19,20)$. Over the course of the disease skeletal muscle 
wasting spreads to the limb girdle musculature, often beginning in the second decade of life (66). The second decade of life is also when cardiac disease is usually first detected (205). Early detection of cardiac conduction defects is essential to prevent sudden death using a number of medical interventions, including a pacemaker and implantable cardioverter defibrillator $(65,192)$.

Skeletal muscle pathology in EDMD can be heterogeneous and is often unreliable for diagnosing EDMD. The pathological skeletal muscle may include variable skeletal muscle fiber size, centralized muscle fiber nuclei, fibrosis, and necrosis (277). Skeletal muscle nuclei also exhibit major nuclear architecture defects (71-73). Because of this unreliability, sequencing of $E M D, L M N A$ or $F H L 1$ is the primary method used for diagnosis.

Alternatively, immunodetection of emerin or FHL1 is performed to diagnose X-EDMD, since $95 \%$ of $E M D$ mutations are nonsense mutations $(14,15,200,210,324)$ and FHL1 protein is significantly reduced or undetectable in FHL1-related X-EDMD (95). There are four emerin disease-causing mutants (S54F, Q133, P183H, and $\Delta 95-99$ ) that are expressed at levels at or near wild-type emerin levels and localize correctly to the nuclear envelope (10, 200). Interestingly, these mutants have less severe phenotypes (324). Immunodetection is often unreliable to diagnose EDMD2 because it is a dominant disease in which wild-type lamins and the mutant lamin proteins are often both expressed; approximately $50 \%$ of EDMD2 patients have reduced lamin A/C protein expression (188). Thus, gene sequencing is the widely accepted diagnostic tool for diagnosing EDMD. Using this analysis EMD is mutated in $61 \%$ of X-EDMD, FHL1 is mutated in $10 \%$ of X-EDMD, and LMNA is mutated in $45 \%$ of EDMD2 $(18,20,26,243,244,310)$. Approximately $64 \%$ of EDMD patients fail to have mutations in EMD, FHL1 or LMNA (95), suggesting there are likely more genes mutated in EDMD, many of which are likely nuclear lamina components.

There are multiple lines of evidence implicating impaired skeletal muscle regeneration in contributing significantly to the skeletal muscle wasting seen in EDMD. First, there is no evidence of increased skeletal muscle damage in EDMD patients, such as increased skeletal muscle fiber permeability. Second, emerin-null mice have delayed muscle regeneration and repair, motor coordination defects, and mild atrioventricular conduction defects, which presents after approximately one year $(186,229)$. Myoblasts derived from emerin-null mice and emerin-downregulated myoblasts exhibit impaired differentiation into multinucleated myotubes $(77,121)$. Skeletal muscle biopsies from EDMD patients and emerin-null mice had increased expression of genes important for skeletal muscle regeneration $(6,186)$. Wingless-related integration site (Wnt), insulin-like growth factor 1 (IGF-1), transforming growth factor-beta (TGF- $\beta$ ), and Notch signaling pathways, which are important for myogenic differentiation and regeneration, are disrupted in emerin-null myogenic progenitors $(39,64,126,127,138,179,241,256)$. The coordinated temporal expression of important differentiation genes, including $M y o D, M y f 5, \operatorname{Pax} 3$, and $\operatorname{Pax} 7$, which is required for skeletal muscle regeneration, is disrupted in emerin-null myogenic progenitors (51). Disruption of the coordinated temporal expression of these genes is caused by the failure of these genomic loci to properly localize to the nuclear periphery when they are repressed during differentiation. 
EDMD was the first disease linked to mutations of nuclear lamina proteins (187). There is now an ever-expanding list of diseases linked to mutations in nuclear lamina proteins collectively known as laminopathies or nuclear envelopathies. The nuclear envelopathies have a wide-spectrum of phenotypes. Many phenotypes may overlap with other nuclear envelopathies, whereas some phenotypes are specific to a particular disease, depending on the gene that is mutated, if the mutation is a nonsense or missense mutation, and the residue that is mutated in missense mutants.

\section{Limb-girdle muscular dystrophy type 1B}

Limb-girdle muscular dystrophy type 1B (LGMD1B) is a disease caused by mutations in the gene encoding lamin A $(202,306)$. It is characterized by weakness in the proximal lower leg muscles followed by progressive weakening of the upper limb muscles $(304,305)$.

LGMD1B also has significant cardiac involvement, including atrioventricular conduction defects. Mild contractures of the elbow and Achilles tendons are rarely seen, but have been reported in some patients. Due to the absence of tendon contractures, it was thought this disease was separate from EDMD. However, recent evidence suggests LGMD1 and EDMD are related and are part of a spectrum of skeletal muscle diseases, the severity of which is likely dependent on genetic modifiers. Dilated cardiomyopathy is also associated with LGMD1B and it has been suggested that dilated cardiomyopathy may be the unifying feature for this spectrum of diseases (165).

\section{Heart-hand syndrome, Slovenian type}

Mutations in $L M N A$ cause Heart-hand syndrome $(255,287)$. Heart-hand syndrome is characterized by adult-onset atrioventricular and sinoatrial conduction defects, dilated cardiomyopathy and ventricular tachycardia. Feet and hand abnormalities are also present in these diseases, characterized by short distal phalanges on the hands and feet.

\section{Restrictive dermopathy}

Restrictive dermopathy is caused by mutations in LMNA or ZMPSTE24 (38, 201, 212, 213, 289). ZMPSTE24 is a metalloproteinase that cleaves the immature, farnesylated form of lamin A to create the mature, unfarnesylated form of lamin A. Restrictive dermopathy results in prenatal death of the infant with only a few reported cases surviving a few days to a month postnatally $(98,100,115,290,319)$. It is characterized by growth retardation, congenital contractures and tight, brittle skin. The tight skin is most evident around the face causing a small mouth and limited jaw mobility.

The pathogenesis of restrictive dermopathy is caused by the failure to properly process prelamin A, resulting in the accumulation and stable association of farnesylated prelamin A at the INM. Mutations in $L M N A$ causing restrictive dermopathy block the processing of prelamin A to the mature form of lamin A (213). Mutations in ZMPSTE24 result in the accumulation of prelamin A $(38,201,212,289)$, due to the inability of ZMPSTE24 to cleave prelamin A. A few patients carrying mutations in ZMPSTE24 lacked lamin A expression, while others maintained lamin A expression. Increased prelamin A levels is also associated with normal aging and premature aging syndromes $(267,268)$. The molecular details underlying prelamin A toxicity will be discussed later in this review. 


\section{Torsion dystonia 1 (DYT1 dystonia)}

Torsion dystonia is caused by a point mutation in the $D Y T 1$ gene that encodes Torsin1A (93). Torsion dystonia is a dominantly inherited central nervous system disease that typically presents in the first or second decade of life and is characterized by prolonged involuntary twisting movements in the trunk, neck, or limbs $(177,178,214)$.

Torsin1A is a member of the AAA+ family of ATPases (230). AAA+ ATPases have a wide range of cellular functions. Torsin1A normally localizes to the endoplasmic reticulum. However the disease-causing Torsin1A mutant localizes to the perinuclear space $(86,88)$. Torsin1 A is highly expressed in neural tissues compared to non-neural tissues (131). There are also other Torsin 1 isoforms that are expressed in tissue-specific patterns, which may explain the neural-specific defects seen in Torsin1A mutants.

The perinuclear space is continuous with the endoplasmic reticulum space. Proteins preferentially localize to these compartments, suggesting there are sorting or retention mechanisms guiding their localization to the perinuclear space or the endoplasmic reticulum. Two proteins are involved in regulating Torsin1A localization, LAP1 and LULL1. LULL1 localizes to the endoplasmic reticulum and binds Torsin1A to retain it there $(211,307)$. LAP1 is found at the INM and the pathogenic Torsin1A mutant preferentially binds LAP1 due to a decrease in the ATPase activity of mutant Torsin 1 A $(89,211)$. How mislocalization of Torsin1A causes disease is not fully understood. However, it is possible the disease may be caused by decreased ATPase activity independent of its nuclear envelope localization.

\section{Dilated cardiomyopathy}

Dilated cardiomyopathy is characterized by enlargement of the heart and reduced systolic function (132). Dilated cardiomyopathy is the most common form of cardiomyopathy and accounts for a majority of heart transplants in young children and young adults. Mutations in the genes encoding LAP2, emerin and lamin A/C, and others, can cause dilated cardiomyopathy. Mutations in these genes can cause isolated dilated cardiomyopathy, but more often, these mutations also have some skeletal muscle involvement (e.g., LGMD1B and EDMD). The skeletal muscle involvement can range from mild to severe and is thought to be caused by genetic modifiers $(69,165,202)$. Dilated cardiomyopathy with conduction system defects is the leading cause of death in patients with mutations in lamin $\mathrm{A} / \mathrm{C}$, emerin, and LAP2 (321).

\section{Pelger-Huet anomaly}

Pelger-Huet anomaly (PHA) is characterized by abnormal nuclear shape and altered chromatin organization in granulocytes (114). PHA is caused by mutations in the gene encoding LBR, an integral INM protein. Nuclei in granulocytes are normally rod shaped or dumbbell shaped. Hypolobulated nuclei with coarse chromatin are seen in neutrophils of patients in which one allele of LBR is mutated. Neutrophil nuclei in patients with mutations in both alleles are more ovoid. These homozygous patients often exhibit developmental delays, epilepsy, or skeletal abnormalities. 
A related, but rarer disease is caused by homozygous mutations in LBR and called Greenberg skeletal dysplasia (314). Greenberg dysplasia is lethal in utero and is characterized by severe shortening of long bones, the motheaten appearance of all bones, disorganization of chondrosseaus calcification and unusual ossification centers $(91,139)$. How homozygous LBR mutations cause two diseases with phenotypes ranging from mild (PHA) to severe (Greenberg dysplasia; 224) has yet to be determined, but genetic modifiers likely play a role.

\section{Spinocerebellar ataxia}

Spinocerebellar ataxia is characterized by late onset cerebellar ataxia, often accompanied by distal limb weakness and muscular atrophy $(61,62,92,124)$. Mutations in $S Y N E 1$ cause spinocerebellar ataxia and in most cases, no functional protein is produced. $S Y N E 1$ encodes nesprin-1, a component of the LINC complex $(33,282)$. The LINC complex connects the cytoskeletal and nucleoskeletal networks through a network of interactions in the cytoplasm, the nucleus and within the nuclear envelope $(33,40,101)$. Nesprin-1 has been implicated in providing nuclear structure, transducing mechanical signals from the cytoskeleton to the nucleus to effect gene expression, regulating cell signaling, and regulating nuclear positioning during development and during chemotaxis (33$35,76,90,157,166,167,215,251,272,312,329,330)$. How these functions of nesprin-1 are related to the pathology of spinocerebellar ataxia is unclear. Additionally, $S Y N E 1$ encodes over 30 predicted nesprin-1 isoforms (248) and it is unclear which nesprin-1 isoform is responsible for the pathogenesis of spinocerebellar ataxia.

\section{Buschke-Ollendorff syndrome and osteopoikilosis}

Buschke-Ollendorff syndrome is a connective tissue disorder characterized by subcutaneous nevi or nodules that can be either elastin rich or collagen rich (109). Buschke-Ollendorff syndrome is an autosomal dominant disorder caused by mutations in LEMD3, which encodes the integral inner membrane protein MAN1. Buschke-Ollendorff syndrome is often accompanied by osteopoikilosis, which is characterized by "spotty bones" most often appearing in the long bones, but it can sometimes be seen in the pelvis.

MAN1 is a founding member of the LEM-domain family of inner integral membrane proteins that bind the chromatin protein BAF via their LEM domain (174). MAN1 also binds directly to emerin, which is thought to regulate emerin or MAN1 activity, or both (174). Importantly, MAN1 also regulates SMAD-dependent signaling by attenuating SMAD activity through direct binding to regulatory SMADs $(9,225,234,249)$. Thus, BuschkeOllendorff syndrome and osteopoikilosis are predicted to result from altered TGF- $\beta$ or BMP signaling. However, the mechanism(s) for how mutations in MAN1 cause these diseases remains unknown.

\section{Progeroid syndromes}

Hutchinson-Gilford progeria syndrome (HGPS) is a premature aging syndrome that usually presents within the first or second year of life (110). HGPS is characterized by joint contractures, sclerotic skin, growth impairment, and vascular disease. A majority of HGPS patients fail to live past the second decade of life due to a significant increase in the risk of 
stroke or myocardial infarction (189). HGPS is an autosomal dominant syndrome caused by sporadic mutations in $L M N A(47,68)$.

The LMNA mutation that causes HGPS is a silent mutation at glycine 608 that changes a cytosine to a thymidine and also generates a splice donor site $(47,68)$. The introduction of the splice donor site results in production of a lamin A mutant that lacks 50 amino acids in its carboxyl-terminal tail. This deleted region contains the endoproteolytic site for ZMPSTE24, which is a metalloproteinase that cleaves the immature, farnesylated form of lamin A to create the mature, unfarnesylated form of lamin A. The presence of farnesylated lamin A causes significantly more lamin A to stably associate with the nuclear envelope via insertion of the farnesyl group into the lipid bilayer, leading to a more rigid, less elastic nuclear lamina, and increased nuclear fragility (43). It is unclear if the deletion of the 50 residues from the carboxy-terminus contributes to the HGPS phenotype. I predict this may contribute to the HGPS phenotype, since restrictive der-mopathy is caused by the presence of unprocessed, farnesylated prelamin A containing these 50 residues and has a much different phenotype than HGPS.

Atypical Werner's syndrome is a premature aging syndrome that presents at a later age than HGPS (e.g., second or third decade of life), but shares similarities with HGPS $(37,57,253)$. Atypical Werner's syndrome is caused by mutations in $L M N A$, often occurring in the first two coiled-coil domains of the lamin A protein. Premature aging, short stature, cardiovascular pathology, osteoporosis, lipodystrophy, and muscular atrophy characterize atypical Werner's syndrome. Some patients also have atrophic skin, loss of subcutaneous tissues and premature graying or hair loss. Insulin-resistant diabetes mellitus are also seen in some patients.

Atypical progeria syndrome shares many similarities with HGPS, but has some distinct features. Atypical progeria does not have the cardiovascular defects seen in HGPS, but is characterized by generalized lipoatrophy, severe osteoporosis, and marked osteolysis (245). Unlike HGPS, mutations in LMNA or ZPMSTE24 are not associated with atypical progeria. Rather, mutations in $B A N F 1$, which encodes the nonspecific chromatin-binding protein that binds to the LEM domain of INM proteins, cause atypical progeria (245). Based on the crystal structure of BAF, mutations causing atypical progeria are not predicted to effect emerin or DNA binding or BAF dimerization. Future studies are needed to test how BAF mutations causing atypical progeria affect BAF structure or function, or both, to cause disease.

\section{Mandibuloacral dysplasia}

Mandibuloacral dysplasia (MAD) is caused by mutations in LMNA or ZMPSTE24 (2, 3, $197,216,279,284)$. MAD is an autosomal recessive disorder characterized by skeletal abnormalities with progressive osteolysis of the clavicles and distal phalanges, craniofacial abnormalities with mandibular hypoplasia, growth retardation, and lipodystrophy. The lipodystrophy in MAD manifests as loss of fat from peripheral body parts, such as the limbs, and the presence of normal or increased fat in the trunk and neck region. 
Lamin A mutations causing MAD commonly cause argi-nine residue 527 to change to histidine $(216,279,284)$. It is unclear how this mutation specifically causes MAD, but not other syndromes associated with mutations in lamin A. However, one study found matrix metalloproteinase 9 (MMP9) was upregulated more than 4.5-fold, suggesting overexpression of MMP9 may play a role in the pathology of MAD (163). ZMPSTE24 mutations causing MAD are often compound heterozygous mutations, whereby one allele contains a nonsense mutation in ZMPSTE24 and the other allele contains a missense mutation in ZMPSTE24. How these missense mutations effect ZMPSTE24 activity is not known, nor is it understood how the compound heterozygous mutations in ZMPSTE24 specifically cause MAD.

\section{Familial partial lipodystrophy type 2}

Familial Partial Lipodystrophy type 2 (FPLD2) is a metabolic disorder characterized by abnormal fat distribution with presentation occurring in the second to third decade of life (80). FPLD2 is characterized by gradual fat loss in the upper and lower extremities, the gluteus and the trunk, resulting in a muscular appearance $(60,80,136)$. This is often accompanied by fat accumulation in the neck and face. Insulin resistant diabetes and hypertriglyceridemia are frequent metabolic abnormalities associated with FPLD2. FPLD2 is an autosomal dominant disorder caused by mutations in $\operatorname{LMNA}(32,150,271,278,292)$. Mutations causing FPLD2 occur at arginine 482 in lamin A. The most common mutations at residue 482 change arginine to glutamine or tryptophan, although one case has been reported where a mutation from arginine to histidine occurred.

How lamin A mutations at residue 482 cause FPLD2 is not known, although the two main hypotheses are lamin A R482Q/W mutations cause defective nuclear structure or lamin A $\mathrm{R} 482 \mathrm{Q} / \mathrm{W}$ mutations alter gene expression. Supporting the nuclear structure hypothesis, nuclei from FPLD2 patients or from cells expressing lamin A R482Q/W mutants have altered nuclear lamina architecture, often exhibiting a honeycomb appearance $(25,308)$. Defective nuclear lamina structure is predicted to alter nuclear architecture and is hypothesized to contribute to the FPLD2 phenotype. How these changes in nuclear lamina architecture affect nuclear integrity or gene expression is not known. Supporting the gene expression hypothesis, significant epigenetic changes are detected in cells expressing lamin A R482Q/W mutants, including altered peripheral heterochromatin organization, which results in changes in gene expression (97). Other studies also reported changes in gene expression in lamin A R482Q/W mutants (303), suggesting transcriptional changes in the adipogenic gene expression program may contribute to the pathology of FPLD2. These gene expression changes are likely caused by the altering the association of lamin $\mathrm{A} / \mathrm{C}$ with SREBP, a transcription factor that regulates hundreds of genes associated with lipogenesis and lipid metabolism (303).

\section{Charcot-Marie tooth disorder}

Charcot-Marie Tooth type 2 disorder 2B1 (CMT2B1) is an autosomal recessive, peripheral neuropathy caused by mutations in $L M N A$ (48). The mutation substitutes an arginine for a cysteine at residue 298, which is located within the rod domain of lamin A. CMT2B1 is characterized by axonal peripheral neuropathy with high variability in the age of presentation and disease progression (296). Mouse models of CMT2B1 were created that 
contain the analogous $L M N A$ mutation. The phenotype in mice is similar to the human disease, as the mice have reduced axon density and enlarged, demyelinated axons (48). Further analysis of this CMT2B1 mouse model is anticipated to yield insights into the disease mechanism and lead to the development of possible therapies.

\section{Adult-onset demyelinating leukodystrophy}

Adult-onset demyelinating leukodystrophy (ADLD) is a slow-progressing, fatal neurological disorder that presents in the fourth or fifth decade of life. ADLD is characterized by autonomic abnormalities and widespread symmetric demyelination of the central nervous system (231). ADLD is caused by duplication of the $L M N B 1$ gene, resulting in a twofold increase in lamin B expression $(231,273)$. It remains to be determined how increased lamin B expression causes demyelination.

\section{Nuclear Envelope Protein Function}

In this section, the function of various nuclear envelope proteins will be discussed, with a focus on those implicated in disease. These functions will include the regulation of nuclear structure, chromatin architecture, nuclear transport, mRNA splicing, cell signaling, gene expression, and mechanotransduction. I will start with emerin, as it has been the focus of intense study ever since it was identified as mutated in EDMD.

\section{Emerin}

Human emerin is a 254 amino acid protein containing a 220 amino acid $\mathrm{N}$-terminal nucleoplasmic domain, a 23 amino acid C-terminal transmembrane domain and an 11residue luminal domain (137; Fig. 1). Emerin has no known secondary structure outside of the LEM-domain (320) and the transmembrane domain despite many attempts to obtain structural data by NMR and crystallography. However, functional studies using emerin mutants and emerin deletions identified several regions of emerin important for its localization and function $(226,301)$. Emerin residues 109-175 were shown to mediate the localization of emerin to the INM, while residues 110-147 are necessary and sufficient for transport of emerin into the nucleus $(226,301)$. Many domains in emerin were identified that bind to a number of proteins involved in a wide range of cellular functions. The many proposed cellular functions of emerin are summarized in Figure 2 and Table 2.

Emerin is ubiquitously expressed $(171,210,302)$ and is implicated in regulating nuclear structure, genomic architecture, cell signaling, and gene expression (50-52,102,117-120, $138,176)$. Supporting roles of emerin in regulating nuclear architecture, emerin binds directly to A-type lamins via the IgG-fold domain in the C-terminus of lamin A (264). Emerin binding to lamins is required for its INM localization $(226,227,294)$. Emerin-null cells and lamin A-null cells, which mislocalize emerin, also have defects in nuclear structure and mechanotransduction $(146,147,149,259)$. Supporting the role of emerin in regulating genomic organization and gene expression, emerin binds directly to many transcription regulators and chromatin repressive enzymes and regulates their activity $(52,102,116,118$, $119,176,318)$. Recent evidence also shows that loss or mutations in emerin alter many cell 
signaling pathways across many cell types and during myogenic differentiation $(51,121$, $138,176,203,206)$.

Emerin is a founding member of the LEM-domain family of proteins, named for a conserved domain shared between $\underline{L} A P 2 \beta$, emerin, and $\underline{\text { MAN1}}$. The LEM domain is necessary and sufficient for binding barrier to autointegration factor (BAF), a nonspecific chromatinbinding protein $(154,175,199,274,275)$. The LEM-domain comprises the N-terminal 44 residues of emerin. The LEM-domain adopts a helix-loop-helix fold that is conserved from prokaryotes to eukaryotes $(30,154,159,320)$. Proteins containing the LEM domain are conserved throughout the metazoan lineage $(22,173)$. Many of the LEM-domain proteins are implicated in targeting or stably tethering chromatin to the nuclear envelope either by directly binding to BAF or other chromatin-associated proteins $(51,52,120,291)$.

Emerin regulates transcription factor activity-It is predicted emerin regulates the expression of a large number of muscle and cardiac genes $(6,138,186)$ by binding directly to and regulating the activity of transcription regulators and chromatin-modifying enzymes, many of which are predicted to be muscle or cardiac specific. Emerin binds many transcription regulators, including GCL (116), Btf (102), Lmo7 (118), $\beta$-catenin (176), SIKE (manuscript in preparation), and BAF (154; Fig. 1). Emerin binding to these proteins regulates the expression of their target genes. Emerin also binds the splicing factor YT521-B (318). How emerin preferentially binds specific transcription regulators in specific tissues (i.e., GCL vs. Lmo7) is currently not known. Further, other emerin-binding transcription regulators and chromatin-modifying enzymes that are cardiac or skeletal muscle specific may not have been identified yet. Lastly, tissue-specific emerin posttranslational modifications may regulate emerin binding to specific transcription or chromatin regulators in heart or muscle, which have yet to be determined. Understanding the mechanism for how emerin regulates gene expression in heart and skeletal muscle and identifying the specific genes regulated by emerin will provide significant insight into muscle disease.

GCL-Germ cell-less (GCL) is a transcription repressor that binds the DP3 subunit of the E2F-DP3 heterodimer to inactivate E2F-DP3-mediated transcription (45) and inhibit entry into S-phase. GCL binds directly to emerin via regulator binding domain (RBD) 1 and RBD-2 in emerin (116; Fig. 1). Emerin downregulation mislocalizes GCL to the cytoplasm, concomitant with increased E2F-mediated gene expression (116). It was concluded emerin binding to GCL represses E2F-and DP3-dependent transcription (120). E2F-DP3-dependent genes are required for entry into $\mathrm{S}$-phase and are repressed by $\mathrm{Rb}$, thereby implicating emerin in regulating cell proliferation and cell cycle exit. Supporting this hypothesis, increased proliferation is seen in emerin-null cells (176). GCL was also found to interact with the germ line-specific protein GAGE, a protein highly upregulated in cancer (83-85). GCL recruits GAGE to the nuclear envelope in cancer cell lines. Thus, emerin may also influence cancer progression by regulating cancer cell proliferation through its interaction with GCL.

Btf-BCL-2-associated transcription factor (Btf; Bclaf1) is a transcription factor that interacts with members of the BCL-2 protein family (130). Btf binds directly to emerin using emerin RBD-1 and RBD-2 (102). Overexpression of Btf induces apoptosis, which is 
inhibited by the expression of BCL-2 protein family members. Btf is released from Bcl-2 and Bcl-xL in the cytoplasm upon induction of apoptosis (254) and accumulates at the nuclear envelope $(102,130)$. Btf also localizes to sites of DNA damage containing histone $\mathrm{H} 2 \mathrm{AX}$ (155) to activate p53 (162). Btf may also function as an mRNA splicing factor $(102,190,262)$, as Btf was also found to associate with ribonucleoprotein complexes (266). Btf was shown to play crucial roles in development, as Btf-null mice have polydactyly, have immune system abnormalities and die prematurely due to incomplete lung development (183). How emerin binding to Btf regulates Btf function during development remains undefined.

Lmo7-Lim-domain-only 7 (Lmo7) is a transcription factor that shuttles between the plasma membrane and nucleus in many cell types (118). Lmo7 binds directly to emerin with high-affinity using RBD-1 and 2 of emerin. Lmo7 is highly expressed in cardiac and skeletal muscle, suggesting its interaction with emerin may be important for the EDMD disease mechanism $(246,276)$. Interestingly, the nuclear localization of Lmo7 is dependent on emerin expression $(118,223)$. Emerin binding to Lmo7 inhibits activation of its target genes, including emerin. Thus, it was proposed emerin binding to Lmo7 acts in a negative feedback loop to act as a rheostat to control emerin levels in the cell (118).

The functional interaction between $\mathrm{Lmo} 7$ and emerin is important for regulating the expression of myogenic differentiation genes to ensure proper differentiation. Lmo7 binds to and activates the promoters of important myogenic differentiation genes, including Pax3, $M y o D$, and Myf5 (50). Emerin binding to Lmo7 blocks Lmo7 binding to these promoters resulting in inhibition of Lmo7 activation of Pax3, MyoD, and Myf5 (50). Expression of Pax 3, MyoD, and Myf5 is downregulated at different stages of myogenic differentiation; this repression is tightly regulated during differentiation. Repression of Pax3, MyoD, and Myf5 expression coincides with increased emerin expression. Increased emerin expression causes Lmo7 to the move to the nuclear periphery and to the cytoplasm, suggesting emerin either stimulates Lmo7 nuclear export or blocks Lmo7 nuclear import to inhibit Lmo7 activation of its target genes (50). In mature myotubes Lmo7 localizes predominantly to the cytoplasm with some $\mathrm{Lmo} 7$ at the plasma membrane, where it can interact with focal adhesion proteins $(118,323)$. Localization of $\mathrm{Lmo} 7$ to the cytoplasm and plasma membrane upon myotube formation and maturation suggests Lmo7 may have important roles in mature muscle, including muscle cell adaptation and attachment of skeletal muscle to the extracellular matrix.

Loss of Lmo7 expression in mice causes phenotypes consistent with neuromuscular disease. An Lmo7-null mouse was generated using gene-trap technology to analyze if loss of Lmo7 in mice had skeletal muscle and cardiac phenotypes consistent with EDMD. These Lmo7null mice were also used to test if $\mathrm{Lmo} 7$ was important for skeletal muscle structure and function. Lmo7-null mice were smaller and had smaller skeletal muscle fibers with larger skeletal muscle nuclei, compared to wild-type littermates (208). Importantly, Lmo7-null mice failed a battery of neuromuscular tests designed to determine if Lmo7-null mice had neuromuscular defects; Lmo7-null mice did. Lmo7-null mice also had decreased cardiac function. Similar to other mouse models of EDMD, Lmo7-null mice had less phosphorylated $\mathrm{Rb}$, extracellular signal-regulated kinase (ERK) and Jun amino-terminal 
kinase (JNK) consistent with altered Rb and mitogen-activated protein kinase (MAPK) signaling. These phenotypes are similar to other EDMD mouse models suggesting the interaction of Lmo7 with emerin is important for the EDMD mechanism.

Surprisingly, loss of Lmo7 expression in mice using different gene-targeting approaches and a different genetic background failed to exhibit skeletal muscle or cardiac dysfunction nor have defective $\mathrm{Rb}$ and MAPK signaling (151). The authors of this study suggested the first Lmo7-null mouse line generated by Lmo7 gene-trap technology may have only removed the largest Lmo7 isoform, which is the major isoform in skeletal muscle $(145,260)$, whereas their mice lacked expression of all Lmo7 isoforms. There are two other major isoforms of Lmo7, one of which is expressed at low levels in skeletal muscle and one of which is the major Lmo7 isoform expressed in the heart. The lack of any discernible phenotypes in this second mouse model could also be due to being created on a different genetic background. It is well established that genetic background can have major effects on disease severity, particularly neuromuscular disease models $(111,112)$. It will be important to determine if the different phenotypes seen in these two Lmo7-null mice strains may result from selective deletion of only the largest isoform in the gene-trap mouse and if so, how the expression of the other Lmo7 isoforms in these mice causes the skeletal muscle and cardiac phenotypes; and how deletion of the other Lmo7 isoforms rescues neuro-muscular disease in the recently developed Lmo7-null line.

$\beta$-Catenin-Emerin binds to and inhibits the nuclear accumulation of $\beta$-catenin. Emerin binds directly to $\beta$-catenin through the adenomatous polyposis coli (APC)-like domain in emerin, which is also RBD-2 (176). Emerin inhibits $\beta$-catenin activity by preventing its accumulation in the nucleus. By restricting the accumulation of $\beta$-catenin in the nucleus, emerin expression represses the expression of $\beta$-catenin target genes (176). Loss of emerin or expression of emerin lacking the APC-like domain caused accumulation of $\beta$-catenin in the nucleus, resulting in increased expression of $\beta$-catenin target genes and increased cell proliferation. Increased $\beta$-catenin protein levels in emerin-null fibroblasts undergoing adipogenic conversion had reduced protein degradation (298). Knockdown of $\beta$-catenin also caused decreased emerin expression (298), suggesting emerin and $\beta$-catenin regulate the expression of $\beta$-catenin and emerin, respectively. Wnt signaling is important for myogenic progenitor cell maintenance (228) and differentiation (23), suggesting the interaction between these two proteins is important for regulating myogenic differentiation and skeletal muscle regeneration.

BAF-Barrier-to-autointegration factor (BAF) is a highly conserved 89 residue protein essential for post-mitotic nuclear assembly (175), cell viability (274), postmitotic nuclear assembly, and cell cycle progression $(79,104)$. BAF helps orchestrate reformation of the nuclear envelope during mitosis. In anaphase, BAF is targeted to "core" regions of the mitotic chromosomes, which are near the spindle attachment sites of telophase chromosomes. BAF then recruits lamin A and emerin to these core regions during nuclear envelope reassembly $(41,103,105)$. BAF is ubiquitously expressed but BAF appears to have tissue-specific functions, since Caenorhabditis elegans lacking BAF affect mainly tissuespecific functions including gonadal cell migration, vulva formation, muscle maintenance 
and germ-line survival and maturation (175). How BAF deletion causes tissue-specific defects remains unknown.

BAF interacts with many endogenous nuclear proteins. BAF directly binds all LEM-domain proteins tested (7). BAF binds directly to lamin A (116). BAF interacts with CRX, a homeobox transcription factor, which inhibits CRX activity (311). Thus, BAF may directly regulate gene expression by inhibiting the activity of related homeobox transcription factors. BAF also binds histones H3 and H4 and selected linker histones, such as H1.1 (199) to help condense DNA via looping (288). BAF overexpression influences many post-translational histone modifications including both those that are associated with transcription repression and activation (198). Thus, BAF regulation of gene expression may also result from BAF regulating chromatin architecture surrounding genes regulated by BAF expression.

Emerin and BAF may also have roles in regulating DNA repair. Emerin and BAF associate with DNA repair proteins (Cul4a and DDB2) after UV exposure, suggesting BAF and emerin have important roles in the DNA damage response (198). Further, emerin-null $C$. elegans are hypersensitive to DNA damage (56). HeLa cells lacking emerin or expressing mutant lamin A show reduced levels of phosphorylated histone H2AX, a marker of DNA damage, in response to DNA cross-linking agents $(11,12,172)$, suggesting emerin promotes genomic stability. Collectively, these data support roles for emerin and BAF in the DNA damage response. Thus, BAF and emerin may be important in cancer progression.

Emerin in cell signaling-Evidence over the last 10 years has demonstrated a significant role for emerin in cell signaling. Emerin loss causes altered expression of genes encoding components of intracellular signaling pathways important for myogenic differentiation. Loss of emerin leads to the altered expression of genes encoding components of the Wnt, TGF $\beta$, IGF-1, and Notch pathways (138). As discussed earlier, emerin loss increases the nuclear accumulation of $\beta$-catenin, leading to increased expression of Wnt-regulated genes and increased cell proliferation (176). The Wnt signaling pathway regulates myoblast proliferation (228) and commitment to myogenic differentiation (23), suggesting increased Wnt signaling in the absence of emerin may contribute to the impaired myogenic differentiation seen in EDMD. Expression of components of the JNK, MAPK, ERK and NF$\kappa \mathrm{B}$, and integrin signaling pathways are also altered in both humans and mice $(203,204$, 207, 322). Interestingly, ERK inhibition that prevents dilated cardiomyopathy in EDMD mouse models (203) also rescues differentiation in emerin- and LMNA-knockdown cells $(70,121)$. Thus, disruption of these pathways in emerin-null myoblasts is predicted to contribute to the impaired differentiation seen in EDMD. How disruption of important myogenic signaling pathways upon loss of emerin expression contributes to the EDMD disease mechanism remains to be determined. Understanding how Wnt, TGF $\beta$, Notch, IGF, JNK, ERK, MAPK, NF- $\kappa$ B, and integrin signaling pathways regulate muscle regeneration and cardiac function and how these functions are disrupted in EDMD will be important for developing therapeutic treatments for EDMD.

Emerin in nuclear structure-Emerin is important for maintaining nuclear architecture. Biophysical studies showed emerin-null cells have decreased elasticity (259) and the nuclear membrane is more malleable $(147,259)$. At the cellular level, skeletal muscle, smooth 
muscle and fibroblast nuclei from X-EDMD patients have abnormal nuclear shape $(72,73)$. Emerin-null mouse embryonic fibroblasts (MEFs) also have increased nuclear deformability, impaired viability upon mechanical strain and defective mechanotransduction, which is similar to that seen in lamin A-null MEFs $(147,149)$. This is not surprising, as emerin binding to lamins is required for emerin localization to the INM; in the absence of lamins, emerin localizes to the endoplasmic reticulum $(226,227,294)$. Whether these structural defects contribute to EDMD pathology remains controversial (259).

Emerin binds to many structural proteins in the nucleus, including nuclear actin, nuclear myosin I, nuclear protein 4.1R and aII-spectrin $(117,119)$. Until recently, these proteins were thought to be exclusively cytoplasmic. Nuclear actin has roles in regulating gene expression, nuclear transport, and sensing cellular stress $(46,236)$. Actin is predicted to regulate nuclear structure by interacting with nuclear pore-linked filaments (135) and emerin (117). Emerin caps the pointed end of actin filaments and stabilizes actin filaments in vitro (117). F-actin is seen in nuclei in vivo $(235,265)$, where it plays important roles in many nuclear functions, including gene expression, chromatin architecture and nuclear structure. Short, nuclear actin filaments are predicted to be associated with the nuclear envelope through its interaction with emerin. Emerin also binds other important structural proteins in the nucleus to form an actin-based nucleoskeleton, including nuclear myosin I and the nuclear-specific spectrin isoform aII (119). Emerin copurifies in vivo with nuclear protein 4.1R, which binds both spectrin and actin $(218,219,239) .4 .1 \mathrm{R}$ is required for mitotic spindle formation and nuclear assembly $(142,143)$, suggesting the nucleoskeleton has essential functions during mitosis, one of which may be to serve as a scaffold during spindle formation and nuclear reassembly. Emerin and 4.1R localization is dependent on one another and mislocalization of either protein from the INM causes increased nuclear accumulation of $\beta$-catenin $(176,194)$. Collectively, these interactions are predicted to form a stable nucleoskeleton containing lamin filaments and actin filaments linked to the lamina through its association with lamins and INM proteins $(285,286)$.

Emerin in chromatin architecture-Recent evidence shows the nuclear lamina preferentially associates with repressed chromatin $(74,94,144,195,238,252,280)$. Further demonstrating the lamina as an actively repressive environment, ectopic targeting of active genes to the nuclear lamina represses their transcription $(74,252)$. It is unclear how repressed chromatin is established or maintained at the nuclear envelope, but over the past few years, multiple clues are beginning to emerge. Some repressed domains associated with the lamina using an extended stretch of GAGA repeats (333). Other repressed genomic regions associate with the nuclear lamina in a sequence-independent manner. Localization of repressed chromatin to the nuclear lamina at the nuclear periphery requires the sequential methylation of his-tone 3 on Lysine 9 (H3K9me; 240, 299). Recently, an INM protein (CEC-4) was identified in $C$. elegans that mediated the interaction of repressed chromatin containing $\mathrm{H} 3 \mathrm{~K} 9 \mathrm{me} 2 / 3$ with the nuclear periphery (87). A mammalian homolog of CEC-4 could not be identified. It is predicted that many redundant proteins may exist to tether H3K9me $2 / 3$ chromatin to the periphery, including the interaction of HP1, which binds methylated H3K9, with LBR (220). Undoubtedly, other proteins exist to mediate repressive chromatin localization to the nuclear periphery, given its importance for regulating cell type- 
and differentiation-specific transcriptional programs. Recently, our lab found emerin was required for targeting of repressed myogenic loci to the nuclear periphery during myogenic differentiation via the interaction between emerin and $\operatorname{HDAC} 3(51,52)$. Future studies will be needed to elucidate the underlying mechanisms mediating the interaction of repressed chromatin with the nuclear lamina to establish, maintain or reinforce chromatin repression at the nuclear lamina in mammalian cells.

Ultrastructural and microscopic studies indicated emerin might be important for chromatin organization in mammalian cells. Emerin-null cells have less compacted chromatin $(184,193,217)$ and fibroblasts (184) and skeletal muscle (72) from EDMD patients have altered chromatin organization. Emerin-null myogenic progenitors also had increased levels of chromatin modifications associated with relaxed chromatin architecture (52).

Recently, biochemical and cell biological evidence demonstrates emerin plays an important role in initiating, recruiting or maintaining repressed chromatin at the nuclear lamina. The functional interaction between emerin and histone deacetylase 3 (HDAC3) was shown to be important for localizing repressed chromatin to the nuclear lamina at the nuclear envelope. Emerin binds directly to HDAC3 and interacts with other core components of the nuclear corepressor (NCoR) complex (119), a repressive chromatin complex. Emerin binding to HDAC 3 increases HDAC 3 activity 2.5-fold (52). The interaction between emerin and HDAC3 is required for the coordinated spatiotemporal nuclear envelope localization of genomic regions containing essential myogenic genes, including Myf5, MyoD, and Pax 7 , during myogenic differentiation (52). Activation of HDAC3 catalytic activity rescued subnuclear localization of these gene loci and their expression (51), suggesting HDAC3 catalytic activity is sufficient for localizing repressed chromatin to the nuclear envelope in the absence of emerin. Notably, LAP2 $\beta$ was also reported to interact with HDAC3 (291), suggesting HDAC 3 activation in emerin-null cells may increase the association of HDAC3 with LAP2 $\beta$ to drive repressed chromatin to the nuclear envelope. Disruption of the interaction between emerin and HDAC 3 alters the temporal expression of these myogenic differentiation genes. Importantly, EDMD-causing emerin mutants fail to bind HDAC3 (52), suggesting the functional interaction between emerin and HDAC3 may be important for the EDMD disease mechanism.

The recruitment of repressed chromatin to the nuclear periphery during the cell cycle is also under intense study. Recruitment to the periphery is thought to occur during nuclear reassembly after mitosis, since LADs can dissociate from the nuclear lamina and move to the interior upon treatment with HDAC inhibitors, but withdrawal of these inhibitors does not cause movement of these loci to the periphery (333). Localization of these repressed loci to the periphery requires nuclear envelope disassembly and reassembly $(252,333)$ and is thought to occur by targeting specific INM-containing nuclear envelope vesicles to repressed chromatin during nuclear envelope reassembly. Because BAF and specific nuclear lamina components, including emerin, localize to specific chromatin regions during nuclear envelope reassembly (105), it is predicted that the recruitment of specific nuclear envelope proteins to specific chromatin regions form the distinct domains within the nuclear envelope to establish active (e.g., at the NPC) and repressive domains (e.g., at the nuclear lamina) at the nuclear envelope. 


\section{Posttranslational modification and regulation of emerin}

Emerin is extensively posttranslationally modified. Emerin posttranslational modifications are predicted to regulate emerin binding to its many binding partners. Emerin contains nearly 40 known phosphorylation sites $(4,16,24,31,44,53,81,99,113,169,221,222,233$, $257,258,261,293,295,297,300)$. Emerin is phosphorylated during both interphase and mitosis, but the proteins responsible for phosphorylating emerin and how emerin phosphorylation on specific residues regulates emerin function are just beginning to be understood. Kinases that phosphorylate emerin include the serine/threonine kinases PKA (258), GSK3 $\beta$ (315), PKC $\beta$ (153), and ERK2/MAPK (27). Src, Abl (Y167), and Her2 mediate tyrosine phosphorylation of emerin $(21,297)$. Undoubtedly, there are many more kinases responsible for residue-specific phosphorylation of emerin. It will be interesting to test if phosphorylation of one emerin residue recruits other kinases to further phosphorylate emerin on other residues to affect emerin structure or activity, or both.

Emerin is also modified by the addition of $O$-linked $\beta$ - $N$-Acetylglucosamine ( $O$-GlcNAc; 11). $O$-GlcNAcylation is a nutrient and stress sensor $(325,326)$ and often regulates transcription (250), the deposition of epigenetic marks (263), and cell signaling (107). $O$ GlcNAc has extensive crosstalk with phosphorylation and can either compete with or enhance phosphorylation (107). Emerin is $O$-GlcNAc-modified at eight sites (11), one of which is Ser54, which is mutated to phenylalanine (S54F) in EDMD.

Emerin posttranslational modifications effect the binding of known emerin-binding proteins, although only a few emerin partners have been studied to date. Tyrosine and serine/threonine phosphorylation regulates emerin binding to $\operatorname{BAF}(258,297)$. Differential phosphorylation of emerin also regulates the interaction of emerin with actin (152). $O$-GlcNAcylation and phosphorylation of Ser173 have opposite effects on emerin binding to BAF, as $O$-GlcNAc increases emerin binding to BAF, but $\mathrm{S} 173$ phosphorylation reduces emerin BAF binding (11). $O$-GlcNAcylated emerin increased its binding to lamin B and chromatin (e.g., histone H3) and phosphorylated emerin had increased binding to lamin A (11). Differential posttranslational modifcation of emerin is predicted to establish niches at the nuclear envelope that contain distinct proteins, similar to lipid rafts at the plasma membrane. It will be important to determine how each emerin posttranslational modifcation affects binding to each of its partners and how these modifications affect specific functions of emerin, including nuclear structure, gene expression and chromatin architecture.

\section{Lamins}

The nuclear lamina is a proteinaceous network underlying the nuclear envelope $(1,58,75$, 182). The nuclear lamina was initially defined by its biochemical properties, which included resistance to high salt and detergent (63). At the microscopic level, the nuclear lamina appeared as a 3 brous structure that is composed of type- $\mathrm{V}$ intermediate filaments known as nuclear lamins.

There are two major classes of lamins, A-type and B-type lamins. The A-type lamins are lamin A, lamin C, lamin A $\Delta 10$, and lamin $\mathrm{C} 2$. These lamins are alternatively spliced products of the $L M N A$ gene (161). Lamin A and $\mathrm{C}$ are the predominant isoforms expressed 
in differentiated cell types (334). Lamins A and C are not expressed at detectable levels in stem cells. Lamin A $\Delta 10$ can be detected at low levels in many different cell types and appear to be expressed highest during development (168). However, its function in development remains unclear. Lamin $\mathrm{C} 2$ is a meiosis-specific lamin isoform (125). B-type lamins are encoded by two genes, $L M N B 1$ and $L M N B 2$, which encode lamin $\mathrm{B} 1$ and lamin $\mathrm{B} 2$ and $\mathrm{B} 3$, respectively $(13,160)$. Unlike A-type lamins, B-type lamins are anchored in the INM by prenylation of a cysteine residue at its C-terminus (82). Lamin B1 and B2 are expressed in all cell types, while lamin B3 is only expressed in the germ line $(8,78,156)$.

The structure of lamins and their polymerization into filaments is similar to other classes of intermediate filament proteins. Lamins consist of a globular head domain followed by a long central rod domain, which is responsible for lamin dimerization, and a C-terminal globular domain containing an IgG fold. The IgG-fold domain mediates the interaction of lamin A with many of its binding partners to regulate many diverse functions. These proteins include the structural protein actin, emerin, the DNA replication protein PCNA, and matrin-3, a component of the nuclear matrix $(54,283,286)$. Lamins first polymerize to form homodimers through dimerization of their rod domains $(49,281)$. It should be noted that there is in vitro evidence supporting the formation of heterodimers (270). After dimerization, lamins further polymerize by lamin dimers associating in a head-to-tail configuration, followed by lateral associations of these polymerized dimers underlying the INM $(1,129$, 316).

Differential posttranslational processing of lamins A, B and C is dictated by their amino acid sequence. Lamin A is synthesized as a precursor called prelamin A that is proteolytically processed to its mature form. Lamin A has a CAAX box at its C-terminus that is initially modified by farnesylation. Following this modifcation prelamin A is further processed by cleavage of the last 18 residues by ZMPSTE24 to generate mature lamin A. Lamin C is a splice variant of lamin A and thus lamin A and C share the first 566 residues. Lamin $\mathrm{C}$ has a unique six residue $\mathrm{C}$-terminal tail $(49,281)$ and thus it is not posttranslationally processed. Lamin B also contains a CAAX box at its C-terminus that is farnesylated; however, it is not cleaved by ZMPSTE24. Due to the hydrophobic farnesyl group on lamin B, lamin B inserts into the INM, to cause stable association of lamin B with the nuclear envelope. Lamin A is not inserted into the nuclear envelope because the farnesyl group is cleaved by ZMPSTE24. Thus, lamin A/C filaments are also found in the nuclear interior. Lamin A localization at the INM is thus thought to result from its association with lamin B filaments.

For more comprehensive analysis of lamin function in nuclear structure and function, please see recent reviews by C. J. Hutchison and Azibani et al. $(5,122)$. However, the role of the nuclear lamina in chromatin organization is discussed due to this newly identified and vitally important role for lamins in regulating genomic architecture to regulate gene expression.

Lamins in chromatin organization-The nuclear lamina preferentially associates with repressed chromatin. Approximately $40 \%$ of the genome associates with the nuclear envelope in large regions with sharp borders $(0.1-10 \mathrm{Mb}$; 94,238) called lamina-associated domains (LADs) in both humans and flies. LADs are largely heterochromatic and are characterized by the enrichment of chromatin modifications associated with repressed 
chromatin $(123,237)$. LADs are also highly enriched in repetitive DNA and are gene poor. LAD organization is relatively stable in differentiated cells but LAD organization is dramatically altered during cellular differentiation (237) and in response to extracellular signals. For example, genomic regions containing genes activated during differentiation of neural progenitor cells (e.g., brain development) lose their association with the nuclear lamina during differentiation, while genes that are turned off (e.g., cell cycle) are recruited to the nuclear lamina (237). Changes in nuclear lamina association correlated well with changes in the expression of genes within these loci.

There are two classes of LADs, constitutive LADs (cLADs), which are stably associated with the nuclear lamina, and facultative LADs (fLADs), which vary from cell type to cell type and during development (191). cLADs have high A/T content, whereas fLADs tend to have normal A/T content. Thus, it was proposed that some LADs might associate with the nuclear lamina in a sequence-dependent manner.

Evidence for sequence-dependent association of LADs with the nuclear lamina comes from studies by Zullo and colleagues (333). Ectopic insertion of small sequences from LADs, named lamina-associated sequences (LASs), into chromatin normally found in the nuclear interior was sufficient to reposition this chromatin to the nuclear envelope post-mitotically (333). LASs also repressed transcription of a cointegrated reporter gene. Thus, LASs are sufficient to localize chromatin to the nuclear lamina and repress gene expression. The minimal LAS necessary and sufficient for nuclear lamina localization and gene repression was an extended GAGA motif of at least 10 GAGA repeats. LASs interact directly with the transcriptional repressor cKrox. LASs bound to cKrox also formed a complex with HDAC3 and LAP2 $\beta$, which was suggested to mediate the transcriptional repression and INM localization of LADs, respectively. Surprisingly, single cell analyses of LADs during mitosis suggested LAD targeting to the nuclear lamina was not sequence dependent, but rather dependent on the chromatin state of the $\operatorname{LAD}(106,133)$. Thus, to what extent the localization of LADs to the nuclear lamina is sequence dependent remains controversial.

It will be important to determine how LAD organization is disrupted in lamin A or lamin B mutants that cause disease, since disruption of chromatin architecture is predicted to cause massive changes in the transcriptome, both in differentiated cells and during development and tissue regeneration. We predict the wide spectrum of phenotypes, and the heterogeneity of these phenotypes, seen in different nuclear lamina protein mutations causing the same disease (e.g., EDMD) may result from changes in chromatin architecture in a protein- and mutation-specific manner. For example, one mutation in lamin A may preferentially effect binding to a specific chromatin-associated protein, while another lamin A mutation effects binding to a different chromatin-associated protein. These interactions would be predicted to alter genomic organization in specific ways. Thus tissue-specific expression of INM proteins, various chromatin-associated proteins, transcription factors, and cell signaling components are predicted to further compound these effects.

\section{The LINC complex}

The linker of nucleoskeleton and cytoskeleton (LINC) complex connects the cytoskeleton to the nucleoskeleton to transmit mechanical forces from the cytoskeleton to the nucleus 
$(164,185)$. The LINC complex is implicated in many cellular processes, including cell division (181), cytoskeletal organization (331), and organelle positioning (134). The ONM components of the LINC complex are nesprins, a large family of spectrin-repeat transmembrane proteins (313) that bind actin or microtubules of the cytoskeleton depending on the nesprin isoform $(328,331)$. Nesprins interact with the C-terminus of SUN-domain proteins that are located in the lumen of the nuclear envelope $(101,232)$. SUN-domain proteins are essential for the localization of nesprins to the ONM $(170,180)$. The binding of SUN-domain proteins to nesprins is required for maintaining the size of the lumen between the INM and the ONM $(40,285)$. This interaction is also required nuclear positioning in myofibers $(29,36,96,157)$.

In addition to maintaining nuclear structure and nuclear positioning, the LINC complex also mediates the transmission of mechanical forces from the plasma membrane through the cytoskeleton to the nucleoskeleton to activate mechanosensitive genes $(147,149,164)$. LINC complex proteins transduce these signals through lamin A/C to directly transmit mechanical forces to the nucleus. Emerin and lamin A directly bind nesprins and SUNdomain proteins $(40,101,196)$. Demonstrating the role of INM proteins in mechanotransduction, emerin-null and lamin A/C-null cells have defective mechanotransduction and increased nuclear fragility $(146,148,259)$. Emerin is required for activation of mechanosensitive genes, including IEX-1 and EGR-1. Interestingly, mutations in the cytoskeletal protein desmin increase AD-EDMD severity (209), suggesting this protein may also function in the LINC complex. Thus mutations in emerin or lamin A are also predicted to disrupt LINC complex formation and function, which may contribute to the EDMD disease mechanism $(285,327)$.

\section{Conclusion}

In the last two decades since the identification of emerin and lamins as the cause of EDMD genetic, cellular, and biochemical studies have led to significant insights into the functions of nuclear envelope proteins. However, many questions remain unanswered. Since the identification of mutations in these nuclear envelope proteins as the cause for EDMD, many other diseases have been identified that are caused by mutations in lamins and many INM proteins. Unfortunately, the function of lamins and INM proteins remain ill-defined. As was discussed in this review, nuclear lamina proteins are implicated in many different cellular functions. Thus, it is imperative that the field identifies the lamin and INM protein functions important for disease-specific pathology. Once these functions are identified, it will be equally important to determine how different functions of an INM protein are regulated by posttranslational modifications and how they are affected by disease-specific mutations. Particularly important will be to comprehensively study the interplay between INM protein posttranslational modifcation and the regulation of genomic organization, gene expression and cell signaling. How mechanotransduction through the LINC complex affects gene expression and how it is altered in disease is also an area that requires further study.

The tissue specificity of laminopathies remains poorly understood. However, it is predicted that tissue specific expression of nuclear lamina proteins with functional overlap contribute to the tissue specificity of laminopathies. Thus, it is essential to define these overlapping 
functions of nuclear lamina proteins to identify the tissue-specific pathways disrupted by mutations in particular nuclear lamina proteins. This will aid in the development of pharmacological and cellular therapies for laminopathies. The generation of better animal models for these diseases is essential for identifying these pathways and testing therapies for laminopathies.

One of the inherent difficulties in finding treatments for laminopathies is the diverse number of cellular functions nuclear lamina proteins influence and the large number of partners it may act through. To ensure progress continues in understanding the mechanisms underlying the numerous laminopathies, it is crucially important that basic cell biological and biochemical research, as well as disease-focused research, on the function of nuclear lamina proteins be well supported.

\section{Acknowledgments}

The author would like to thank Cam Collins and other members of the Holaska Lab for their assistance in the preparation of this review. The author would like to thank the University of the Sciences and the Department of Pharmaceutical Sciences for funding.

\section{References}

1. Aebi U, Cohn J, Buhle L, Gerace L. The nuclear lamina is a meshwork of intermediate-type filaments. Nature. 1986; 323:560-564. [PubMed: 3762708]

2. Agarwal AK, Fryns JP, Auchus RJ, Garg A. Zinc metalloproteinase, ZMPSTE24, is mutated in mandibuloacral dysplasia. Hum Mol Genet. 2003; 12:1995-2001. [PubMed: 12913070]

3. Ahmad Z, Zackai E, Medne L, Garg A. Early onset mandibuloacral dysplasia due to compound heterozygous mutations in ZMPSTE24. Am J Med Genet A. 2010; 152A:2703-2710. [PubMed: 20814950]

4. Amanchy R, Kalume DE, Iwahori A, Zhong J, Pandey A. Phosphoproteome analysis of HeLa cells using stable isotope labeling with amino acids in cell culture (SILAC). J Proteome Res. 2005; 4:1661-1671. [PubMed: 16212419]

5. Azibani F, Muchir A, Vignier N, Bonne G, Bertrand AT. Striated muscle laminopathies. Semin Cell Dev Biol. 2014; 29:107-115. [PubMed: 24440603]

6. Bakay M, Wang Z, Melcon G, Schiltz L, Xuan J, Zhao P, Sartorelli V, Seo J, Pegoraro E, Angelini C, Shneiderman B, Escolar D, Chen YW, Winokur ST, Pachman LM, Fan C, Mandler R, Nevo Y, Gordon E, Zhu Y, Dong Y, Wang Y, Hoffman EP. Nuclear envelope dystrophies show a transcriptional fingerprint suggesting disruption of $\mathrm{Rb}-\mathrm{MyoD}$ pathways in muscle regeneration. Brain. 2006; 129:996-1013. [PubMed: 16478798]

7. Barton LJ, Soshnev AA, Geyer PK. Networking in the nucleus: A spotlight on LEM-domain proteins. Curr Opin Cell Biol. 2015; 34:1-8. [PubMed: 25863918]

8. Benavente R, Krohne G, Franke WW. Cell type-specific expression of nuclear lamina proteins during development of Xenopus laevis. Cell. 1985; 41:177-190. [PubMed: 3888407]

9. Bengtsson L. What MAN1 does to the Smads. TGFbeta/BMP signaling and the nuclear envelope. FEBS J. 2007; 274:1374-1382. [PubMed: 17489095]

10. Bengtsson L, Wilson KL. Multiple and surprising new functions for emerin, a nuclear membrane protein. Curr Opin Cell Biol. 2004; 16:73-79. [PubMed: 15037308]

11. Berk JM, Maitra S, Dawdy AW, Shabanowitz J, Hunt DF, Wilson KL. O-GlcNAc regulates emerin binding to BAF in a chromatin- and lamin B-enriched 'niche'. J Biol Chem. 2013; 288:3019230209. [PubMed: 24014020]

12. Berk JM, Tifft KE, Wilson KL. The nuclear envelope LEM-domain protein emerin. Nucleus. 2013; 4:298-314. [PubMed: 23873439] 
13. Biamonti G, Giacca M, Perini G, Contreas G, Zentilin L, Weighardt F, Guerra M, Della VG, Saccone S, Riva S, Falaschi A. The gene for a novel human lamin maps at a highly transcribed locus of chromosome 19 which replicates at the onset of S-phase. Mol Cell Biol. 1992; 12:34993506. [PubMed: 1630457]

14. Bione S, Maestrini E, Rivella S, Mancini M, Regis S, Romeo G, Toniolo D. Identification of a novel X-linked gene responsible for Emery-Dreifuss muscular dystrophy. Nat Genet. 1994; 8:323327. [PubMed: 7894480]

15. Bione S, Small K, Aksmanovic VM, D’Urso M, Ciccodicola A, Merlini L, Morandi L, Kress W, Yates JR, Warren ST. Identification of new mutations in the Emery-Dreifuss muscular dystrophy gene and evidence for genetic heterogeneity of the disease. Hum Mol Genet. 1995; 4:1859-1863. [PubMed: 8595407]

16. Boersema PJ, Foong LY, Ding VM, Lemeer S, van Breukelen B, Philp R, Boekhorst J, Snel B, den Hertog J, Choo AB, Heck AJ. In-depth qualitative and quantitative profiling of tyrosine phosphorylation using a combination of phosphopeptide immunoaffinity purification and stable isotope dimethyl labeling. Mol Cell Proteomics. 2010; 9:84-99. [PubMed: 19770167]

17. Bonne G, Di Barletta MR, Varnous S, Becane HM, Hammouda EH, Merlini L, Muntoni F, Greenberg CR, Gary F, Urtizberea JA, Duboc D, Fardeau M, Toniolo D, Schwartz K. Mutations in the gene encoding lamin A/C cause autosomal dominant Emery-Dreifuss muscular dystrophy. Nat Genet. 1999; 21:285-288. [PubMed: 10080180]

18. Bonne G, Mercuri E, Muchir A, Urtizberea A, Becane HM, Recan D, Merlini L, Wehnert M, Boor R, Reuner U, Vorgerd M, Wicklein EM, Eymard B, Duboc D, Penisson-Besnier I, Cuisset JM, Ferrer X, Desguerre I, Lacombe D, Bushby K, Pollitt C, Toniolo D, Fardeau M, Schwartz K, Muntoni F. Clinical and molecular genetic spectrum of autosomal dominant Emery-Dreifuss muscular dystrophy due to mutations of the lamin A/C gene. Ann Neurol. 2000; 48:170-180. [PubMed: 10939567]

19. Bonne G, Mercuri E, Muchir A, Urtizberea A, Becane HM, Recan D, Merlini L, Wehnert M, Boor R, Reuner U, Vorgerd M, Wicklein EM, Eymard B, Duboc D, Penisson-Besnier I, Cuisset JM, Ferrer X, Desguerre I, Lacombe D, Bushby K, Pollitt C, Toniolo D, Fardeau M, Schwartz K, Muntoni F. Clinical and molecular genetic spectrum of autosomal dominant Emery-Dreifuss muscular dystrophy due to mutations of the lamin A/C gene. Ann Neurol. 2000; 48:170-180. [PubMed: 10939567]

20. Bonne G, Yaou RB, Beroud C, Boriani G, Brown S, de Visser M, Duboc D, Ellis J, HausmanowaPetrusewicz I, Lattanzi G, Merlini L, Morris G, Muntoni F, Opolski G, Pinto YM, Sangiuolo F, Toniolo D, Trembath R, van Berlo JH, van der Kooi AJ, Wehnert M. 108th ENMC International Workshop, 3rd Workshop of the MYO-CLUSTER project: EUROMEN, 7th International EmeryDreifuss Muscular Dystrophy (EDMD) Workshop, 13-15 September 2002, Naarden, The Netherlands. Neuromuscul Disord. 2003; 13:508-515. [PubMed: 12899879]

21. Bose R, Molina H, Patterson AS, Bitok JK, Periaswamy B, Bader JS, Pandey A, Cole PA. Phosphoproteomic analysis of Her2/neu signaling and inhibition. Proc Natl Acad Sci U S A. 2006; 103:9773-9778. [PubMed: 16785428]

22. Brachner A, Foisner R. Evolvement of LEM proteins as chromatin tethers at the nuclear periphery. Biochem Soc Trans. 2011; 39:1735-1741. [PubMed: 22103517]

23. Brack AS, Conboy IM, Conboy MJ, Shen J, Rando TA. A temporal switch from notch to Wnt signaling in muscle stem cells is necessary for normal adult myogenesis. Cell Stem Cell. 2008; 2:50-59. [PubMed: 18371421]

24. Brill LM, Salomon AR, Ficarro SB, Mukherji M, Stettler-Gill M, Peters EC. Robust phosphoproteomic profiling of tyrosine phosphorylation sites from human T cells using immobilized metal affinity chromatography and tandem mass spectrometry. Anal Chem. 2004; 76:2763-2772. [PubMed: 15144186]

25. Broers JL, Kuijpers HJ, Ostlund C, Worman HJ, Endert J, Ramaekers FC. Both lamin A and lamin $\mathrm{C}$ mutations cause lamina instability as well as loss of internal nuclear lamin organization. Exp Cell Res. 2005; 304:582-592. [PubMed: 15748902]

26. Brown CA, Lanning RW, McKinney KQ, Salvino AR, Cherniske E, Crowe CA, Darras BT, Gominak S, Greenberg CR, Grosmann C, Heydemann P, Mendell JR, Pober BR, Sasaki T, Shapiro F, Simpson DA, Suchowersky O, Spence JE. Novel and recurrent mutations in lamin A/C in 
patients with Emery-Dreifuss muscular dystrophy. Am J Med Genet. 2001; 102:359-367. [PubMed: 11503164]

27. Bukong TN, Hall WW, Jacque JM. Lentivirus-associated MAPK/ERK2 phosphorylates EMD and regulates infectivity. J Gen Virol. 2010; 91:2381-2392. [PubMed: 20463147]

28. Burke B, Stewart CL. The nuclear lamins: Flexibility in function. Nat Rev Mol Cell Biol. 2013; 14:13-24. [PubMed: 23212477]

29. Cadot B, Gache V, Gomes ER. Moving and positioning the nucleus in skeletal muscle - one step at a time. Nucleus. 2015; 6:373-381. [PubMed: 26338260]

30. Cai MHY, Ghirlando R, Wilson KL, Craigie R, Clore GM. Solution structure of the constant region of nuclear envelope protein LAP2 reveals two LEM-domain structures: One binds BAF and the other binds DNA. EMBO J. 2001; 20:4399-4407. [PubMed: 11500367]

31. Cantin GT, Yi W, Lu B, Park SK, Xu T, Lee JD, Yates JR 3rd. Combining protein-based IMAC, peptide-based IMAC, and MudPIT for efficient phosphoproteomic analysis. J Proteome Res. 2008; 7:1346-1351. [PubMed: 18220336]

32. Cao H, Hegele RA. Nuclear lamin A/C R482Q mutation in canadian kindreds with Dunnigan-type familial partial lipodystrophy. Hum Mol Genet. 2000; 9:109-112. [PubMed: 10587585]

33. Cartwright S, Karakesisoglou I. Nesprins in health and disease. Semin Cell Dev Biol. 2014; 29:169-179. [PubMed: 24374011]

34. Chambliss AB, Khatau SB, Erdenberger N, Robinson DK, Hodzic D, Longmore GD, Wirtz D. The LINC-anchored actin cap connects the extracellular milieu to the nucleus for ultrafast mechanotransduction. Sci Rep. 2013; 3:1087. [PubMed: 23336069]

35. Chancellor TJ, Lee J, Thodeti CK, Lele T. Actomyosin tension exerted on the nucleus through nesprin-1 connections influences endothelial cell adhesion, migration, and cyclic strain-induced reorientation. Biophys J. 2010; 99:115-123. [PubMed: 20655839]

36. Chang W, Folker ES, Worman HJ, Gundersen GG. Emerin organizes actin flow for nuclear movement and centrosome orientation in migrating fibroblasts. Mol Biol Cell. 2013; 24:38693880. [PubMed: 24152738]

37. Chen L, Lee L, Kudlow BA, Dos Santos HG, Sletvold O, Shafeghati Y, Botha EG, Garg A, Hanson NB, Martin GM, Mian IS, Kennedy BK, Oshima J. LMNA mutations in atypical Werner's syndrome. Lancet. 2003; 362:440-445. [PubMed: 12927431]

38. Chen M, Kuo HH, Huang YC, Ke YY, Chang SP, Chen CP, Lee DJ, Lee ML, Lee MH, Chen TH, Chen CH, Lin HM, Liu CS, Ma GC. A case of restrictive dermopathy with complete chorioamniotic membrane separation caused by a novel homozygous nonsense mutation in the ZMPSTE24 gene. Am J Med Genet A. 2009; 149A:1550-1554. [PubMed: 19504603]

39. Conboy IM, Rando TA. The regulation of Notch signaling controls satellite cell activation and cell fate determination in postnatal myogenesis. Dev Cell. 2002; 3:397-409. [PubMed: 12361602]

40. Crisp M, Liu Q, Roux K, Rattner JB, Shanahan C, Burke B, Stahl PD, Hodzic D. Coupling of the nucleus and cytoplasm: Role of the LINC complex. J Cell Biol. 2006; 172:41-53. [PubMed: 16380439]

41. Dabauvalle MC, Muller E, Ewald A, Kress W, Krohne G, Muller CR. Distribution of emerin during the cell cycle. Eur J of Cell Biol. 1999; 78:749-756. [PubMed: 10569247]

42. Dahl KN, Kalinowski A. Nucleoskeleton mechanics at a glance. J Cell Sci. 2011; 124:675-678. [PubMed: 21321324]

43. Dahl KN, Scaffidi P, Islam MF, Yodh AG, Wilson KL, Misteli T. Distinct structural and mechanical properties of the nuclear lamina in Hutchinson-Gilford progeria syndrome. Proc Natl Acad Sci U S A. 2006; 103:10271-10276. [PubMed: 16801550]

44. Daub H, Olsen JV, Bairlein M, Gnad F, Oppermann FS, Korner R, Greff Z, Keri G, Stemmann O, Mann M. Kinase-selective enrichment enables quantitative phosphoproteomics of the kinome across the cell cycle. Mol Cell. 2008; 31:438-448. [PubMed: 18691976]

45. de la Luna S, Allen KE, Mason SL, La Thangue NB. Integration of a growth-suppressing BTB/POZ domain protein with the DP component of the E2F transcription factor. EMBO J. 1999; 18:212-228. [PubMed: 9878064]

46. de Lanerolle P. Nuclear actin and myosins at a glance. J Cell Sci. 2012; 125:4945-4949. [PubMed: 23277533] 
47. De Sandre-Giovannoli A, Bernard R, Cau P, Navarro C, Amiel J, Boccaccio I, Lyonnet S, Stewart CL, Munnich A, Le Merrer M, Levy N. Lamin a truncation in Hutchinson-Gilford progeria. Science. 2003; 300:2055. [PubMed: 12702809]

48. De Sandre-Giovannoli A, Chaouch M, Kozlov S, Vallat JM, Tazir M, Kassouri N, Szepetowski P, Hammadouche T, Vandenberghe A, Stewart CL, Grid D, Levy N. Homozygous defects in LMNA, encoding lamin A/C nuclear-envelope proteins, cause autosomal recessive axonal neuropathy in human (Charcot-Marie-Tooth disorder type 2) and mouse. Am J Hum Genet. 2002; 70:726-736. [PubMed: 11799477]

49. Dechat T, Adam SA, Taimen P, Shimi T, Goldman RD. Nuclear lamins. Cold Spring Harb Perspect Biol. 2010; 2:a000547. [PubMed: 20826548]

50. Dedeic Z, Cetera M, Cohen TV, Holaska JM. Emerin inhibits Lmo7 binding to the Pax3 and MyoD promoters and expression of myoblast proliferation genes. J Cell Sci. 2011; 124:1691-1702. [PubMed: 21525034]

51. Demmerle J, Koch AJ, Holaska JM. Emerin and histone deacetylase 3 (HDAC3) cooperatively regulate expression and nuclear positions of MyoD, Myf5, and Pax7 genes during myogenesis. Chromosome Res. 2013; 21:765-779. [PubMed: 24062260]

52. Demmerle J, Koch AJ, Holaska JM. The nuclear envelope protein Emerin binds directly to histone deacetylase 3 (HDAC3) and activates HDAC3 activity. J Biol Chem. 2012; 287:22080-22088. [PubMed: 22570481]

53. Dephoure N, Zhou C, Villen J, Beausoleil SA, Bakalarski CE, Elledge SJ, Gygi SP. A quantitative atlas of mitotic phosphorylation. Proc Natl Acad Sci U S A. 2008; 105:10762-10767. [PubMed: 18669648]

54. Depreux FF, Puckelwartz MJ, Augustynowicz A, Wolfgeher D, Labno CM, Pierre-Louis D, Cicka D, Kron SJ, Holaska J, McNally EM. Disruption of the lamin A and matrin-3 interaction by myopathic LMNA mutations. Hum Mol Genet. 2015; 24:4284-4295. [PubMed: 25948554]

55. Dittmer TA, Misteli T. The lamin protein family. Genome Biol. 2011; 12:222. [PubMed: 21639948]

56. Dittrich CM, Kratz K, Sendoel A, Gruenbaum Y, Jiricny J, Hengartner MO. LEM-3 - A LEM domain containing nuclease involved in the DNA damage response in C. elegans. PLoS One. 2012; 7:e24555. [PubMed: 22383942]

57. Doh YJ, Kim HK, Jung ED, Choi SH, Kim JG, Kim BW, Lee IK. Novel LMNA gene mutation in a patient with Atypical Werner's Syndrome. Korean J Intern Med. 2009; 24:68-72. [PubMed: 19270485]

58. Doring V, Stick R. Gene structure of nuclear lamin LIII of Xenopus laevis; a model for the evolution of IF proteins from a lamin-like ancestor. Embo J. 1990; 9:4073-4081. [PubMed: 2249665]

59. Dreifuss FH, Hogan GR. Survival in X-chromosomal muscular dystrophy. Neurology. 1961; 11:734-737. [PubMed: 13724309]

60. Dunnigan MG, Cochrane MA, Kelly A, Scott JW. Familial lipoatrophic diabetes with dominant transmission. A new syndrome. Q J Med. 1974; 43:33-48. [PubMed: 4362786]

61. Dupre N, Gros-Louis F, Bouchard JP, Noreau A, Rouleau GA. SYNE1-related autosomal recessive cerebellar ataxia. In: Pagon RA, Adam MP, Ardinger HH, Wallace SE, Amemiya A, Bean LJH, Bird TD, Dolan CR, Fong CT, Smith RJH, Stephens K, editorsGeneReviews(R). University of Washington, Seattle; Seattle (WA): 1993.

62. Dupre N, Gros-Louis F, Chrestian N, Verreault S, Brunet D, de Verteuil D, Brais B, Bouchard JP, Rouleau GA. Clinical and genetic study of autosomal recessive cerebellar ataxia type 1. Ann Neurol. 2007; 62:93-98. [PubMed: 17503513]

63. Dwyer N, Blobel G. A modified procedure for the isolation of a pore complex-lamina fraction from rat liver nuclei. J Cell Biol. 1976; 70:581-591. [PubMed: 986398]

64. Edwall D, Schalling M, Jennische E, Norstedt G. Induction of insulin-like growth factor I messenger ribonucleic acid during regeneration of rat skeletal muscle. Endocrinology. 1989; 124:820-825. [PubMed: 2912704]

65. Emery AE. Emery-Dreifuss muscular dystrophy-a 40 year retrospective. Neuromuscul Disord. 2000; 10:228-232. [PubMed: 10838246] 
66. Emery AE. Emery-Dreifuss syndrome. J Med Genet. 1989; 26:637-641. [PubMed: 2685312]

67. Emery AEH, Dreifuss FE. Unusual type of benign X-linked muscular dystrophy. J Neurol Neurosurg Psychiat. 1955; 29:338-342.

68. Eriksson M, Brown WT, Gordon LB, Glynn MW, Singer J, Scott L, Erdos MR, Robbins CM, Moses TY, Berglund P, Dutra A, Pak E, Durkin S, Csoka AB, Boehnke M, Glover TW, Collins FS. Recurrent de novo point mutations in lamin A cause Hutchinson-Gilford progeria syndrome. Nature. 2003; 423:293-298. [PubMed: 12714972]

69. Fatkin D, MacRae C, Sasaki T, Wolff MR, Porcu M, Frenneaux M, Atherton J, Vidaillet HJ Jr, Spudich S, De Girolami U, Seidman JG, Seidman CE, Muntoni F, Muehle G, Johnson W, McDonough B. Missense mutations in the rod domain of the lamin A/C gene as causes of dilated cardiomyopathy and conduction-system disease. N Engl J Med. 1999; 341:1715-1724. [PubMed: 10580070]

70. Favreau C, Delbarre E, Courvalin JC, Buendia B. Differentiation of C2C12 myoblasts expressing lamin A mutated at a site responsible for Emery-Dreifuss muscular dystrophy is improved by inhibition of the MEK-ERK pathway and stimulation of the PI3-kinase pathway. Exp Cell Res. 2008; 314:1392-1405. [PubMed: 18294630]

71. Fidzianska A, Glinka Z. Nuclear architecture remodelling in envelopathies. Folia Neuropathol. 2007; 45:47-55. [PubMed: 17594594]

72. Fidzianska A, Hausmanowa-Petrusewicz I. Architectural abnormalities in muscle nuclei. Ultrastructural differences between X-linked and autosomal dominant forms of EDMD. J Neurol Sci. 2003; 210:47-51. [PubMed: 12736087]

73. Fidzianska A, Toniolo D, Hausmanowa-Petrusewicz I. Ultrastructural abnormality of sarcolemmal nuclei in Emery-Dreifuss muscular dystrophy (EDMD). J Neurol Sci. 1998; 159:88-93. [PubMed: 9700709]

74. Finlan LE, Sproul D, Thomson I, Boyle S, Kerr E, Perry P, Ylstra B, Chubb JR, Bickmore WA. Recruitment to the nuclear periphery can alter expression of genes in human cells. PLoS Genet. 2008; 4:e1000039. [PubMed: 18369458]

75. Fisher DZ, Chaudhary N, Blobel G. cDNA sequencing of nuclear lamins A and C reveals primary and secondary structural homology to intermediate filament proteins. Proc Natl Acad Sci U S A. 1986; 83:6450-6454. [PubMed: 3462705]

76. Folker ES, Ostlund C, Luxton GW, Worman HJ, Gundersen GG. Lamin A variants that cause striated muscle disease are defective in anchoring transmembrane actin-associated nuclear lines for nuclear movement. Proc Natl Acad Sci U S A. 2011; 108:131-136. [PubMed: 21173262]

77. Frock RL, Kudlow BA, Evans AM, Jameson SA, Hauschka SD, Kennedy BK. Lamin A/C and emerin are critical for skeletal muscle satellite cell differentiation. Genes Dev. 2006; 20:486-500. [PubMed: 16481476]

78. Furukawa K, Hotta Y. cDNA cloning of a germ cell specific lamin B3 from mouse spermatocytes and analysis of its function by ectopic expression in somatic cells. EMBO J. 1993; 12:97-106. [PubMed: 8094052]

79. Furukawa K, Sugiyama S, Osouda S, Goto H, Inagaki M, Horigome T, Omata S, McConnell M, Fisher PA, Nishida Y. Barrier-to-autointegration factor plays crucial roles in cell cycle progression and nuclear organization in Drosophila. J Cell Sci. 2003; 116:3811-3823. [PubMed: 12902403]

80. Garg A. Acquired and inherited lipodystrophies. N Engl J Med. 2004; 350:1220-1234. [PubMed: 15028826]

81. Ge F, Xiao CL, Yin XF, Lu CH, Zeng HL, He QY. Phosphoproteomic analysis of primary human multiple myeloma cells. J Proteomics. 2010; 73:1381-1390. [PubMed: 20230923]

82. Gerace L, Blobel G. The nuclear envelope lamina is reversibly depolymerized during mitosis. Cell. 1980; 19:277-287. [PubMed: 7357605]

83. Gjerstorff MF, Ditzel HJ. An overview of the GAGE cancer/testis antigen family with the inclusion of newly identified members. Tissue Antigens. 2008; 71:187-192. [PubMed: 18179644]

84. Gjerstorff MF, Harkness L, Kassem M, Frandsen U, Nielsen O, Lutterodt M, Mollgard K, Ditzel HJ. Distinct GAGE and MAGE-A expression during early human development indicate specific roles in lineage differentiation. Hum Reprod. 2008; 23:2194-2201. [PubMed: 18611917] 
85. Gjerstorff MF, Rosner HI, Pedersen CB, Greve KB, Schmidt S, Wilson KL, Mollenhauer J, Besir $\mathrm{H}$, Poulsen FM, Mollegaard NE, Ditzel HJ. GAGE cancer-germline antigens are recruited to the nuclear envelope by germ cell-less (GCL). PLoS One. 2012; 7:e45819. [PubMed: 23029259]

86. Gonzalez-Alegre P, Paulson HL. Aberrant cellular behavior of mutant torsinA implicates nuclear envelope dysfunction in DYT1 dystonia. J Neurosci. 2004; 24:2593-2601. [PubMed: 15028751]

87. Gonzalez-Sandoval A, Towbin BD, Kalck V, Cabianca DS, Gaidatzis D, Hauer MH, Geng L, Wang L, Yang T, Wang X, Zhao K, Gasser SM. Perinuclear anchoring of H3K9-methylated chromatin stabilizes induced cell fate in $C$. elegans embryos. Cell. 2015; 163:1333-1347. [PubMed: 26607792]

88. Goodchild RE, Dauer WT. Mislocalization to the nuclear envelope: An effect of the dystoniacausing torsinA mutation. Proc Natl Acad Sci U S A. 2004; 101:847-852. [PubMed: 14711988]

89. Goodchild RE, Dauer WT. The AAA+ protein torsinA interacts with a conserved domain present in LAP1 and a novel ER protein. J Cell Biol. 2005; 168:855-862. [PubMed: 15767459]

90. Grady RM, Starr DA, Ackerman GL, Sanes JR, Han M. Syne proteins anchor muscle nuclei at the neuromuscular junction. Proc Natl Acad Sci U S A. 2005; 102:4359-4364. [PubMed: 15749817]

91. Greenberg CR, Rimoin DL, Gruber HE, DeSa DJ, Reed M, Lachman RS. A new autosomal recessive lethal chondrodystrophy with congenital hydrops. Am J Med Genet. 1988; 29:623-632. [PubMed: 3377005]

92. Gros-Louis F, Dupre N, Dion P, Fox MA, Laurent S, Verreault S, Sanes JR, Bouchard JP, Rouleau GA. Mutations in SYNE1 lead to a newly discovered form of autosomal recessive cerebellar ataxia. Nat Genet. 2007; 39:80-85. [PubMed: 17159980]

93. Grundmann K, Laubis-Herrmann U, Bauer I, Dressler D, Vollmer-Haase J, Bauer P, Stuhrmann M, Schulte T, Schols L, Topka H, Riess O. Frequency and phenotypic variability of the GAG deletion of the DYT1 gene in an unselected group of patients with dystonia. Arch Neurol. 2003; 60:12661270. [PubMed: 12975293]

94. Guelen L, Pagie L, Brasset E, Meuleman W, Faza MB, Talhout W, Eussen BH, de Klein A, Wessels L, de Laat W, van Steensel B. Domain organization of human chromosomes revealed by mapping of nuclear lamina interactions. Nature. 2008; 453:948-951. [PubMed: 18463634]

95. Gueneau L, Bertrand AT, Jais JP, Salih MA, Stojkovic T, Wehnert M, Hoeltzenbein M, Spuler S, Saitoh S, Verschueren A, Tranchant C, Beuvin M, Lacene E, Romero NB, Heath S, Zelenika D, Voit T, Eymard B, Ben Yaou R, Bonne G. Mutations of the FHL1 gene cause Emery-Dreifuss muscular dystrophy. Am J Hum Genet. 2009; 85:338-353. [PubMed: 19716112]

96. Gundersen GG, Worman HJ. Nuclear positioning. Cell. 2013; 152:1376-1389. [PubMed: 23498944]

97. Hakelien AM, Delbarre E, Gaustad KG, Buendia B, Collas P. Expression of the myodystrophic R453W mutation of lamin A in C2C12 myoblasts causes promoter-specific and global epigenetic defects. Exp Cell Res. 2008; 314:1869-1880. [PubMed: 18396274]

98. Hamel BC, Happle R, Steylen PM, Kollee LA, Stekhoven JH, Nijhuis JG, Rauskolb R, AntonLamprecht I. False-negative prenatal diagnosis of restrictive dermopathy. Am J Med Genet. 1992; 44:824-826. [PubMed: 1481855]

99. Han G, Ye M, Liu H, Song C, Sun D, Wu Y, Jiang X, Chen R, Wang C, Wang L, Zou H. Phosphoproteome analysis of human liver tissue by long-gradient nanoflow LC coupled with multiple stage MS analysis. Electrophoresis. 2010; 31:1080-1089. [PubMed: 20166139]

100. Happle R, Stekhoven JH, Hamel BC, Kollee LA, Nijhuis JG, Anton-Lamprecht I, Steijlen PM. Restrictive dermopathy in two brothers. Arch Dermatol. 1992; 128:232-235. [PubMed: 1739303]

101. Haque F, Lloyd DJ, Smallwood DT, Dent CL, Shanahan CM, Fry AM, Trembath RC, Shackleton S. SUN1 interacts with nuclear lamin A and cytoplasmic nesprins to provide a physical connection between the nuclear lamina and the cytoskeleton. Mol Cell Biol. 2006; 26:37383751. [PubMed: 16648470]

102. Haraguchi T, Holaska JM, Yamane M, Wilson KL, Hiraoka Y. Emerin binding to Btf, a deathpromoting transcriptional repressor, is disrupted by a missense mutation that causes EmeryDreifuss muscular dystrophy. Eur J Biochem. 2004; 271:1035-1045. [PubMed: 15009215] 
103. Haraguchi T, Kojidani T, Koujin T, Shimi T, Osakada H, Mori C, Yamamoto A, Hiraoka Y. Live cell imaging and electron microscopy reveal dynamic processes of BAF-directed nuclear envelope assembly. J Cell Sci. 2008; 121:2540-2554. [PubMed: 18628300]

104. Haraguchi T, Koujin T, Osakada H, Kojidani T, Mori C, Masuda H, Hiraoka Y. Nuclear localization of barrier-to-autointegration factor is correlated with progression of $\mathrm{S}$ phase in human cells. J Cell Sci. 2007; 120:1967-1977. [PubMed: 17519288]

105. Haraguchi T, Koujin T, Segura-Totten M, Lee KK, Matsuoka Y, Yoneda Y, Wilson KL, Hiraoka Y. $\mathrm{BAF}$ is required for emerin assembly into the reforming nuclear envelope. J Cell Sci. 2001; 114:4575-4585. [PubMed: 11792822]

106. Harr JC, Luperchio TR, Wong X, Cohen E, Wheelan SJ, Reddy KL. Directed targeting of chromatin to the nuclear lamina is mediated by chromatin state and A-type lamins. J Cell Biol. 2015; 208:33-52. [PubMed: 25559185]

107. Hart GW, Slawson C, Ramirez-Correa G, Lagerlof O. Cross talk between O-GlcNAcylation and phosphorylation: Roles in signaling, transcription, and chronic disease. Annu Rev Biochem. 2011; 80:825-858. [PubMed: 21391816]

108. Helbling-Leclerc A, Bonne G, Schwartz K. Emery-Dreifuss muscular dystrophy. Eur J Hum Genet. 2002; 10:157-161. [PubMed: 11973618]

109. Hellemans J, Preobrazhenska O, Willaert A, Debeer P, Verdonk PC, Costa T, Janssens K, Menten B, Van Roy N, Vermeulen SJ, Savarirayan R, Van Hul W, Vanhoenacker F, Huylebroeck D, De Paepe A, Naeyaert JM, Vandesompele J, Speleman F, Verschueren K, Coucke PJ, Mortier GR. Loss-of-function mutations in LEMD3 result in osteopoikilosis, Buschke-Ollendorff syndrome and melorheostosis. Nat Genet. 2004; 36:1213-1218. [PubMed: 15489854]

110. Hennekam RC. Hutchinson-Gilford progeria syndrome: Review of the phenotype. Am J Med Genet A. 2006; 140:2603-2624. [PubMed: 16838330]

111. Heydemann A, Ceco E, Lim JE, Hadhazy M, Ryder P, Moran JL, Beier DR, Palmer AA, McNally EM. Latent TGF-beta-binding protein 4 modifies muscular dystrophy in mice. J Clin Invest. 2009; 119:3703-3712. [PubMed: 19884661]

112. Heydemann A, Swaggart KA, Kim GH, Holley-Cuthrell J, Hadhazy M, McNally EM. The superhealing MRL background improves muscular dystrophy. Skelet Muscle. 2012; 2:26. [PubMed: 23216833]

113. Hirano Y, Segawa M, Ouchi FS, Yamakawa Y, Furukawa K, Takeyasu K, Horigome T. Dissociation of emerin from barrier-to-autointegration factor is regulated through mitotic phosphorylation of emerin in a Xeno-pus egg cell-free system. J Biol Chem. 2005; 280:3992539933. [PubMed: 16204256]

114. Hoffmann K, Dreger CK, Olins AL, Olins DE, Shultz LD, Lucke B, Karl H, Kaps R, Muller D, Vaya A, Aznar J, Ware RE, Sotelo Cruz N, Lindner TH, Herrmann H, Reis A, Sperling K. Mutations in the gene encoding the lamin $\mathrm{B}$ receptor produce an altered nuclear morphology in granulocytes (Pelger-Huet anomaly). Nat Genet. 2002; 31:410-414. [PubMed: 12118250]

115. Hoffmann R, Lohner M, Bohm N, Leititis J, Helwig H. Restrictive dermopathy: A lethal congenital skin disorder. Eur J Pediatr. 1993; 152:95-98. [PubMed: 8444237]

116. Holaska J, Lee K, Kowalski A, Wilson K. Transcriptional repressor germ cell-less (GCL) and barrier-to-autointegration factor (BAF) compete for binding to emerin in vitro. J Biol Chem. 2003; 278:6969-6975. [PubMed: 12493765]

117. Holaska JM, Kowalski AM, Wilson KL. Emerin caps the pointed end of actin filaments: Evidence for an actin cortical network at the nuclear inner membrane. PLoS Biol. 2004; 2:1354-1362.

118. Holaska JM, Rais-Bahrami S, Wilson KL. Lmo7 is an emerin-binding protein that regulates the transcription of emerin and many other muscle-relevant genes. Hum Mol Genet. 2006; 15:34593472. [PubMed: 17067998]

119. Holaska JM, Wilson KL. An emerin "proteome": Purification of distinct emerin-containing complexes from HeLa cells suggests molecular basis for diverse roles including gene regulation, mRNA splicing, signaling, mechanosensing, and nuclear architecture. Biochemistry. 2007; 46:8897-8908. [PubMed: 17620012]

120. Holaska JM, Wilson KL. Multiple roles for emerin: Implications for Emery-Dreifuss muscular dystrophy. Anat Rec A Discov Mol Cell Evol Biol. 2006; 288:676-680. [PubMed: 16761279] 
121. Huber MD, Guan T, Gerace L. Overlapping functions of nuclear envelope proteins NET25 (Lem2) and emerin in regulation of extracellular signal-regulated kinase signaling in myoblast differentiation. Mol Cell Biol. 2009; 29:5718-5728. [PubMed: 19720741]

122. Hutchison CJ. B-type lamins in health and disease. Semin Cell Dev Biol. 2014; 29:158-163. [PubMed: 24380701]

123. Ikegami K, Egelhofer T, Strome S, Lieb JD. Caenorhabditis elegans chromosome arms are anchored to the nuclear membrane via discontinuous association with LEM-2. Genome Biol. 2010; 11:R120. [PubMed: 21176223]

124. Izumi Y, Miyamoto R, Morino H, Yoshizawa A, Nishinaka K, Udaka F, Kameyama M, Maruyama H, Kawakami H. Cerebellar ataxia with SYNE1 mutation accompanying motor neuron disease. Neurology. 2013; 80:600-601. [PubMed: 23325900]

125. Jahn D, Schramm S, Benavente R, Alsheimer M. Dynamic properties of meiosis-specific lamin C2 and its impact on nuclear envelope integrity. Nucleus. 2010; 1:273-283. [PubMed: 21327075]

126. Jennische E, Hansson HA. Regenerating skeletal muscle cells express insulin-like growth factor I. Acta Physiol Scand. 1987; 130:327-332. [PubMed: 3300170]

127. Jennische E, Skottner A, Hansson HA. Satellite cells express the trophic factor IGF-I in regenerating skeletal muscle. Acta Physiol Scand. 1987; 129:9-15. [PubMed: 3551503]

128. Jimenez-Escrig A, Gobernado I, Garcia-Villanueva M, Sanchez-Herranz A. Autosomal recessive Emery-Dreifuss muscular dystrophy caused by a novel mutation (R225Q) in the lamin A/C gene identified by exome sequencing. Muscle Nerve. 2012; 45:605-610. [PubMed: 22431096]

129. Karabinos A, Schunemann J, Meyer M, Aebi U, Weber K. The single nuclear lamin of Caenorhabditis elegans forms in vitro stable intermediate filaments and paracrystals with a reduced axial periodicity. J Mol Biol. 2003; 325:241-247. [PubMed: 12488092]

130. Kasof GM, Goyal L, White E. Btf, a novel death-promoting transcriptional repressor that interacts with Bcl-2 related proteins. Mol Cell Biol. 1999; 19:4390-4404. [PubMed: 10330179]

131. Kim CE, Perez A, Perkins G, Ellisman MH, Dauer WT. A molecular mechanism underlying the neural-specific defect in torsinA mutant mice. Proc Natl Acad Sci U S A. 2010; 107:9861-9866. [PubMed: 20457914]

132. Kimura A. Molecular genetics and pathogenesis of cardiomyopathy. J Hum Genet. 2016; 61:4150. [PubMed: 26178429]

133. Kind J, Pagie L, Ortabozkoyun H, Boyle S, de Vries SS, Janssen H, Amendola M, Nolen LD, Bickmore WA, van Steensel B. Single-cell dynamics of genome-nuclear lamina interactions. Cell. 2013; 153:178-192. [PubMed: 23523135]

134. King MC, Drivas TG, Blobel G. A network of nuclear envelope membrane proteins linking centromeres to microtubules. Cell. 2008; 134:427-438. [PubMed: 18692466]

135. Kiseleva E, Drummond SP, Goldberg MW, Rutherford SA, Allen TD, Wilson KL. Actin- and protein-4.1-containing filaments link nuclear pore complexes to subnuclear organelles in Xenopus oocyte nuclei. J Cell Sci. 2004; 117:2481-2490. [PubMed: 15128868]

136. Kobberling J, Dunnigan MG. Familial partial lipodystrophy: Two types of an X linked dominant syndrome, lethal in the hemizygous state. J Med Genet. 1986; 23:120-127. [PubMed: 3712389]

137. Koch AJ, Holaska JM. Emerin in health and disease. Semin Cell Dev Biol. 2014; 29:95-106. [PubMed: 24365856]

138. Koch AJ, Holaska JM. Loss of Emerin alters myogenic signaling and miRNA expression in mouse myogenic progenitors. PLoS One. 2012; 7:e37262. [PubMed: 22606356]

139. Konstantinidou A, Karadimas C, Waterham HR, Superti-Furga A, Kaminopetros P, Grigoriadou M, Kokotas H, Agrogiannis G, Giannoulia-Karantana A, Patsouris E, Petersen MB. Pathologic, radiographic and molecular findings in three fetuses diagnosed with HEM/Greenberg skeletal dysplasia. Prenat Diagn. 2008; 28:309-312. [PubMed: 18382993]

140. Korfali N, Srsen V, Waterfall M, Batrakou DG, Pekovic V, Hutchison CJ, Schirmer EC. A flow cytometry-based screen of nuclear envelope transmembrane proteins identifies NET4/Tmem53 as involved in stress-dependent cell cycle withdrawal. PLoS One. 2011; 6:e18762. [PubMed: 21533191]

141. Korfali N, Wilkie GS, Swanson SK, Srsen V, Batrakou DG, Fairley EA, Malik P, Zuleger N, Goncharevich A, de Las Heras J, Kelly DA, Kerr AR, Florens L, Schirmer EC. The leukocyte 
nuclear envelope proteome varies with cell activation and contains novel transmembrane proteins that affect genome architecture. Mol Cell Proteomics. 2010; 9:2571-2585. [PubMed: 20693407]

142. Krauss SW, Chen C, Penman S, Heald R. Nuclear actin and protein 4.1: Essential interactions during nuclear assembly in vitro. Proc Natl Acad Sci U S A. 2003; 100:10752-10757. [PubMed: 12960380]

143. Krauss SW, Spence JR, Bahmanyar S, Barth AI, Go MM, Czerwinski D, Meyer AJ. Downregulation of protein 4.1R, a mature centriole protein, disrupts centrosomes, alters cell cycle progression, and perturbs mitotic spindles and anaphase. Mol Cell Biol. 2008; 28:22832294. [PubMed: 18212055]

144. Kumaran RI, Spector DL. A genetic locus targeted to the nuclear periphery in living cells maintains its transcriptional competence. J Cell Biol. 2008; 180:51-65. [PubMed: 18195101]

145. Kurihara LJ, Semenova E, Miller W, Ingram RS, Guan XJ, Tilghman SM. Candidate genes required for embryonic development: A comparative analysis of distal mouse chromosome 14 and human chromosome 13q22. Genomics. 2002; 79:154-161. [PubMed: 11829485]

146. Lammerding J, Fong LG, Ji JY, Reue K, Stewart CL, Young SG, Lee RT. Lamins A and C but not lamin B1 regulate nuclear mechanics. J Biol Chem. 2006; 281:25768-25780. [PubMed: 16825190]

147. Lammerding J, Hsiao J, Schulze PC, Kozlov S, Stewart CL, Lee RT. Abnormal nuclear shape and impaired mechanotransduction in emerin-deficient cells. J Cell Biol. 2005; 170:781-791. [PubMed: 16115958]

148. Lammerding J, Lee RT. The nuclear membrane and mechanotransduction: Impaired nuclear mechanics and mechanotransduction in lamin A/C deficient cells. Novartis Found Symp. 2005; 264:264-273. discussion 273-268. [PubMed: 15773759]

149. Lammerding J, Schulze PC, Takahashi T, Kozlov S, Sullivan T, Kamm RD, Stewart CL, Lee RT. Lamin A/C deficiency causes defective nuclear mechanics and mechanotransduction. J Clin Invest. 2004; 113:370-378. [PubMed: 14755334]

150. Lanktree M, Cao H, Rabkin SW, Hanna A, Hegele RA. Novel LMNA mutations seen in patients with familial partial lipodystrophy subtype 2 (FPLD2; MIM 151660). Clin Genet. 2007; 71:183186. [PubMed: 17250669]

151. Lao DH, Esparza MC, Bremner SN, Banerjee I, Zhang J, Veevers J, Bradford WH, Gu Y, Dalton ND, Knowlton KU, Peterson KL, Lieber RL, Chen J. Lmo7 is dispensable for skeletal muscle and cardiac function. Am J Physiol Cell Physiol. 2015 ajpcell 0017702015.

152. Lattanzi G, Cenni V, Marmiroli S, Capanni C, Mattioli E, Merlini L, Squarzoni S, Maraldi NM. Association of emerin with nuclear and cytoplasmic actin is regulated in differentiating myoblasts. Biochem Biophys Res Commun. 2003; 303:764-770. [PubMed: 12670476]

153. Leach N, Bjerke SL, Christensen DK, Bouchard JM, Mou F, Park R, Baines J, Haraguchi T, Roller RJ. Emerin is hyperphosphorylated and redistributed in herpes simplex virus type 1infected cells in a manner dependent on both UL34 and US3. J Virol. 2007; 81:10792-10803. [PubMed: 17652388]

154. Lee KK, Haraguchi T, Lee RS, Koujin T, Hiraoka Y, Wilson KL. Distinct functional domains in emerin bind lamin A and DNA-bridging protein BAF. J Cell Sci. 2001; 114:4567-4573. [PubMed: 11792821]

155. Lee YY, Yu YB, Gunawardena HP, Xie L, Chen X. BCLAF1 is a radiation-induced H2AXinteracting partner involved in gammaH2AX-mediated regulation of apoptosis and DNA repair. Cell Death Dis. 2012; 3:e359. [PubMed: 22833098]

156. Lehner CF, Stick R, Eppenberger HM, Nigg EA. Differential expression of nuclear lamin proteins during chicken development. J Cell Biol. 1987; 105:577-587. [PubMed: 3301871]

157. Lei K, Zhang X, Ding X, Guo X, Chen M, Zhu B, Xu T, Zhuang Y, Xu R, Han M. SUN1 and SUN2 play critical but partially redundant roles in anchoring nuclei in skeletal muscle cells in mice. Proc Natl Acad Sci U S A. 2009; 106:10207-10212. [PubMed: 19509342]

158. Liang WC, Mitsuhashi H, Keduka E, Nonaka I, Noguchi S, Nishino I, Hayashi YK. TMEM43 mutations in Emery-Dreifuss muscular dystrophy-related myopathy. Ann Neurol. 2011; 69:10051013. [PubMed: 21391237] 
159. Lin F, Blake DL, Callebaut I, Skerjanc IS, Holmer L, McBurney MW, Paulin-Levasseur M, Worman HJ. MAN1, an inner nuclear membrane protein that shares the LEM domain with lamina-associated polypeptide 2 and emerin. J Biol Chem. 2000; 275:4840-4847. [PubMed: 10671519]

160. Lin F, Worman HJ. Structural organization of the human gene (LMNB1) encoding nuclear lamin B1. Genomics. 1995; 27:230-236. [PubMed: 7557986]

161. Lin F, Worman HJ. Structural organization of the human gene encoding nuclear lamin A and nuclear lamin C. J Biol Chem. 1993; 268:16321-16326. [PubMed: 8344919]

162. Liu H, Lu ZG, Miki Y, Yoshida K. Protein kinase C delta induces transcription of the TP53 tumor suppressor gene by controlling death-promoting factor Btf in the apoptotic response to DNA damage. Mol Cell Biol. 2007; 27:8480-8491. [PubMed: 17938203]

163. Lombardi F, Fasciglione GF, D’Apice MR, Vielle A, D’Adamo M, Sbraccia P, Marini S, Borgiani P, Coletta M, Novelli G. Increased release and activity of matrix metalloproteinase-9 in patients with mandibuloacral dysplasia type A, a rare premature ageing syndrome. Clin Genet. 2008; 74:374-383. [PubMed: 18554282]

164. Lombardi ML, Lammerding J. Keeping the LINC: The importance of nucleocytoskeletal coupling in intracellular force transmission and cellular function. Biochem Soc Trans. 2011; 39:17291734. [PubMed: 22103516]

165. Lu JT, Muchir A, Nagy PL, Worman HJ. LMNA cardiomyopathy: Cell biology and genetics meet clinical medicine. Dis Model Mech. 2011; 4:562-568. [PubMed: 21810905]

166. Luke Y, Zaim H, Karakesisoglou I, Jaeger VM, Sellin L, Lu W, Schneider M, Neumann S, Beijer A, Munck M, Padmakumar VC, Gloy J, Walz G, Noegel AA. Nesprin-2 Giant (NUANCE) maintains nuclear envelope architecture and composition in skin. J Cell Sci. 2008; 121:18871898. [PubMed: 18477613]

167. Luxton GW, Gomes ER, Folker ES, Vintinner E, Gundersen GG. Linear arrays of nuclear envelope proteins harness retrograde actin flow for nuclear movement. Science. 2010; 329:956959. [PubMed: 20724637]

168. Machiels BM, Zorenc AH, Endert JM, Kuijpers HJ, van Eys GJ, Ramaekers FC, Broers JL. An alternative splicing product of the lamin A/C gene lacks exon 10. J Biol Chem. 1996; 271:92499253. [PubMed: 8621584]

169. Malik R, Lenobel R, Santamaria A, Ries A, Nigg EA, Korner R. Quantitative analysis of the human spindle phosphoproteome at distinct mitotic stages. J Proteome Res. 2009; 8:4553-4563. [PubMed: 19691289]

170. Malone CJ, Misner L, Le Bot N, Tsai MC, Campbell JM, Ahringer J, White JG. The C. elegans hook protein, ZYG-12, mediates the essential attachment between the centrosome and nucleus. Cell. 2003; 115:825-836. [PubMed: 14697201]

171. Manilal S, Nguyen TM, Sewry CA, Morris GE. The Emery-Dreifuss muscular dystrophy protein, emerin, is a nuclear membrane protein. Hum Mol Genet. 1996; 5:801-808. [PubMed: 8776595]

172. Manju K, Muralikrishna B, Parnaik VK. Expression of disease-causing lamin A mutants impairs the formation of DNA repair foci. J Cell Sci. 2006; 119:2704-2714. [PubMed: 16772334]

173. Mans BJ, Anantharaman V, Aravind L, Koonin EV. Comparative genomics, evolution and origins of the nuclear envelope and nuclear pore complex. Cell Cycle. 2004; 3:1612-1637. [PubMed: 15611647]

174. Mansharamani M, Wilson KL. Direct binding of nuclear membrane protein MAN1 to emerin in vitro and two modes of binding to barrier-to-autointegration factor. J Biol Chem. 2005; 280:13863-13870. [PubMed: 15681850]

175. Margalit A, Brachner A, Gotzmann J, Foisner R, Gruenbaum Y. Barrier-to-autointegration factora BAFfiing little protein. Trends Cell Biol. 2007; 17:202-208. [PubMed: 17320395]

176. Markiewicz E, Tilgner K, Barker N, van de Wetering M, Clevers H, Dorobek M, HausmanowaPetrusewicz I, Ramaekers FC, Broers JL, Blankesteijn WM, Salpingidou G, Wilson RG, Ellis JA, Hutchison CJ. The inner nuclear membrane protein emerin regulates beta-catenin activity by restricting its accumulation in the nucleus. EMBO J. 2006; 25:3275-3285. [PubMed: 16858403] 
177. Marsden CD. The problem of adult-onset idiopathic torsion dystonia and other isolated dyskinesias in adult life (including blepharospasm, oromandibular dystonia, dystonic writer's cramp, and torticollis, or axial dystonia). Adv Neurol. 1976; 14:259-276. [PubMed: 941774]

178. Marsden CD, Harrison MJ, Bundey S. Natural history of idiopathic torsion dystonia. Adv Neurol. 1976; 14:177-187. [PubMed: 941771]

179. Massague J, Cheifetz S, Endo T, Nadal-Ginard B. Type beta transforming growth factor is an inhibitor of myogenic differentiation. Proc Natl Acad Sci U S A. 1986; 83:8206-8210. [PubMed: 3022285]

180. McGee MD, Rillo R, Anderson AS, Starr DA. UNC-83 IS a KASH protein required for nuclear migration and is recruited to the outer nuclear membrane by a physical interaction with the SUN protein UNC-84. Mol Biol Cell. 2006; 17:1790-1801. [PubMed: 16481402]

181. McGee MD, Stagljar I, Starr DA. KDP-1 is a nuclear envelope KASH protein required for cellcycle progression. J Cell Sci. 2009; 122:2895-2905. [PubMed: 19638405]

182. McKeon FD, Kirschner MW, Caput D. Homologies in both primary and secondary structure between nuclear envelope and intermediate filament proteins. Nature. 1986; 319:463-468. [PubMed: 3453101]

183. McPherson JP, Sarras H, Lemmers B, Tamblyn L, Migon E, Matysiak-Zablocki E, Hakem A, Azami SA, Cardoso R, Fish J, Sanchez O, Post M, Hakem R. Essential role for Bclaf1 in lung development and immune system function. Cell Death Differ. 2009; 16:331-339. [PubMed: 19008920]

184. Meaburn KJ, Cabuy E, Bonne G, Levy N, Morris GE, Novelli G, Kill IR, Bridger JM. Primary laminopathy fibroblasts display altered genome organization and apoptosis. Aging Cell. 2007; 6:139-153. [PubMed: 17274801]

185. Mejat A, Misteli T. LINC complexes in health and disease. Nucleus. 2010; 1:40-52. [PubMed: 21327104]

186. Melcon G, Kozlov S, Cutler DA, Sullivan T, Hernandez L, Zhao P, Mitchell S, Nader G, Bakay M, Rottman JN, Hoffman EP, Stewart CL. Loss of emerin at the nuclear envelope disrupts the Rb1/E2F and MyoD pathways during muscle regeneration. Hum Mol Genet. 2006; 15:637-651. [PubMed: 16403804]

187. Mendez-Lopez I, Worman HJ. Inner nuclear membrane proteins: Impact on human disease. Chromosoma. 2012; 121:153-167. [PubMed: 22307332]

188. Menezes MP, Waddell LB, Evesson FJ, Cooper S, Webster R, Jones K, Mowat D, Kiernan MC, Johnston HM, Corbett A, Harbord M, North KN, Clarke NF. Importance and challenge of making an early diagnosis in LMNA-related muscular dystrophy. Neurology. 2012; 78:12581263. [PubMed: 22491857]

189. Merideth MA, Gordon LB, Clauss S, Sachdev V, Smith AC, Perry MB, Brewer CC, Zalewski C, Kim HJ, Solomon B, Brooks BP, Gerber LH, Turner ML, Domingo DL, Hart TC, Graf J, Reynolds JC, Gropman A, Yanovski JA, Gerhard-Herman M, Collins FS, Nabel EG, Cannon RO III, Gahl WA, Introne WJ. Phenotype and course of Hutchinson-Gilford progeria syndrome. N Engl J Med. 2008; 358:592-604. [PubMed: 18256394]

190. Merz C, Urlaub H, Will CL, Luhrmann R. Protein composition of human mRNPs spliced in vitro and differential requirements for mRNP protein recruitment. RNA. 2007; 13:116-128. [PubMed: 17095540]

191. Meuleman W, Peric-Hupkes D, Kind J, Beaudry JB, Pagie L, Kellis M, Reinders M, Wessels L, van Steensel B. Constitutive nuclear lamina-genome interactions are highly conserved and associated with A/T-rich sequence. Genome Res. 2013; 23:270-280. [PubMed: 23124521]

192. Meune C, Van Berlo JH, Anselme F, Bonne G, Pinto YM, Duboc D. Primary prevention of sudden death in patients with lamin A/C gene mutations. N Engl J Med. 2006; 354:209-210.

193. Mewborn SK, Puckelwartz MJ, Abuisneineh F, Fahrenbach JP, Zhang Y, MacLeod H, Dellefave L, Pytel P, Selig S, Labno CM, Reddy K, Singh H, McNally E. Altered chromosomal positioning, compaction, and gene expression with a lamin A/C gene mutation. PLoS One. 2010; 5:e14342. [PubMed: 21179469] 
194. Meyer AJ, Almendrala DK, Go MM, Krauss SW. Structural protein 4.1R is integrally involved in nuclear envelope protein localization, centrosome-nucleus association and transcriptional signaling. J Cell Sci. 2011; 124:1433-1444. [PubMed: 21486941]

195. Milon BC, Cheng H, Tselebrovsky MV, Lavrov SA, Nenasheva VV, Mikhaleva EA, Shevelyov YY, Nurminsky DI. Role of histone deacetylases in gene regulation at nuclear lamina. PLoS One. 2012; 7:e49692. [PubMed: 23226217]

196. Mislow JMK, Holaska JM, Kim MS, Lee KK, Segura-Totten M, Wilson KL, McNally EM. Nesprin-1a self-associates and binds directly to emerin and lamin A in vitro. FEBS Lett. 2002; 525:135-140. [PubMed: 12163176]

197. Miyoshi Y, Akagi M, Agarwal AK, Namba N, Kato-Nishimura K, Mohri I, Yamagata M, Nakajima S, Mushiake S, Shima M, Auchus RJ, Taniike M, Garg A, Ozono K. Severe mandibuloacral dysplasia caused by novel compound heterozygous ZMPSTE24 mutations in two Japanese siblings. Clin Genet. 2008; 73:535-544. [PubMed: 18435794]

198. Montes de Oca R, Andreassen PR, Wilson KL. Barrier-to-autointegration factor influences specific histone modifications. Nucleus. 2011; 2:580-590. [PubMed: 22127260]

199. Montes de Oca R, Lee KK, Wilson KL. Binding of barrier to autointegration factor (BAF) to histone H3 and selected linker histones including H1.1. J Biol Chem. 2005; 280:42252-42262. [PubMed: 16203725]

200. Morris GE, Manilal S. Heart to heart: From nuclear proteins to Emery-Dreifuss muscular dystrophy. Hum Mol Genet. 1999; 8:1847-1851. [PubMed: 10469836]

201. Moulson CL, Go G, Gardner JM, van der Wal AC, Smitt JH, van Hagen JM, Miner JH. Homozygous and compound heterozygous mutations in ZMPSTE24 cause the laminopathy restrictive dermopathy. J Invest Dermatol. 2005; 125:913-919. [PubMed: 16297189]

202. Muchir A, Bonne G, van der Kooi AJ, van Meegen M, Baas F, Bolhuis PA, de Visser M, Schwartz $\mathrm{K}$. Identification of mutations in the gene encoding lamins $\mathrm{A} / \mathrm{C}$ in autosomal dominant limb girdle muscular dystrophy with atrioventricular conduction disturbances (LGMD1B). Hum Mol Genet. 2000; 9:1453-1459. Record as supplied by publisher. [PubMed: 10814726]

203. Muchir A, Pavlidis P, Bonne G, Hayashi YK, Worman HJ. Activation of MAPK in hearts of EMD null mice: Similarities between mouse models of X-linked and autosomal dominant Emery Dreifuss muscular dystrophy. Hum Mol Genet. 2007; 16:1884-1895. [PubMed: 17567779]

204. Muchir A, Shan J, Bonne G, Lehnart SE, Worman HJ. Inhibition of extracellular signal-regulated kinase signaling to prevent cardiomyopathy caused by mutation in the gene encoding A-type lamins. Hum Mol Genet. 2009; 18:241-247. [PubMed: 18927124]

205. Muchir A, Worman HJ. Emery-Dreifuss muscular dystrophy. Curr Neurol Neurosci Rep. 2007; 7:78-83. [PubMed: 17217858]

206. Muchir A, Wu W, Worman HJ. Reduced expression of A-type lamins and emerin activates extracellular signal-regulated kinase in cultured cells. Biochim Biophys Acta. 2009; 1792:75-81. [PubMed: 19022376]

207. Muchir A, Wu W, Worman HJ. Reduced expression of A-type lamins and emerin activates extracellular signal-regulated kinase in cultured cells. Biochim Biophys Acta. 2009; 1792:75-81. [PubMed: 19022376]

208. Mull A, Kim G, Holaska JM. LMO7-null mice exhibit phenotypes consistent with EmeryDreifuss muscular dystrophy. Muscle Nerve. 2015; 51:222-228. [PubMed: 24825363]

209. Muntoni F, Bonne G, Goldfarb LG, Mercuri E, Piercy RJ, Burke M, Yaou RB, Richard P, Recan D, Shatunov A, Sewry CA, Brown SC. Disease severity in dominant Emery-Dreifuss is increased by mutations in both emerin and desmin proteins. Brain. 2006; 129:1260-1268. [PubMed: 16585054]

210. Nagano A, Koga R, Ogawa M, Kurano Y, Kawada J, Okada R, Hayashi YK, Tsukahara T, Arahata K. Emerin deficiency at the nuclear membrane in patients with Emery-Dreifuss muscular dystrophy. Nat Genet. 1996; 12:254-259. [PubMed: 8589715]

211. Naismith TV, Dalal S, Hanson PI. Interaction of torsinA with its major binding partners is impaired by the dystonia-associated DeltaGAG deletion. J Biol Chem. 2009; 284:27866-27874. [PubMed: 19651773] 
212. Navarro CL, Cadinanos J, De Sandre-Giovannoli A, Bernard R, Courrier S, Boccaccio I, Boyer A, Kleijer WJ, Wagner A, Giuliano F, Beemer FA, Freije JM, Cau P, Hennekam RC, Lopez-Otin C, Badens C, Levy N. Loss of ZMPSTE24 (FACE-1) causes autosomal recessive restrictive dermopathy and accumulation of Lamin A precursors. Hum Mol Genet. 2005; 14:1503-1513. [PubMed: 15843403]

213. Navarro CL, De Sandre-Giovannoli A, Bernard R, Boccaccio I, Boyer A, Genevieve D, HadjRabia S, Gaudy-Marqueste C, Smitt HS, Vabres P, Faivre L, Verloes A, Van Essen T, Flori E, Hennekam R, Beemer FA, Laurent N, Le Merrer M, Cau P, Levy N. Lamin A and ZMPSTE24 (FACE-1) defects cause nuclear disorganization and identify restrictive dermopathy as a lethal neonatal laminopathy. Hum Mol Genet. 2004; 13:2493-2503. [PubMed: 15317753]

214. Nemeth AH. The genetics of primary dystonias and related disorders. Brain. 2002; 125:695-721. [PubMed: 11912106]

215. Neumann S, Schneider M, Daugherty RL, Gottardi CJ, Eming SA, Beijer A, Noegel AA, Karakesisoglou I. Nesprin-2 interacts with \{alpha\}-catenin and regulates Wnt signaling at the nuclear envelope. J Biol Chem. 2010; 285:34932-34938. [PubMed: 20801886]

216. Novelli G, Muchir A, Sangiuolo F, Helbling-Leclerc A, D’Apice MR, Massart C, Capon F, Sbraccia P, Federici M, Lauro R, Tudisco C, Pallotta R, Scarano G, Dallapiccola B, Merlini L, Bonne G. Mandibuloacral dysplasia is caused by a mutation in LMNA-encoding lamin A/C. Am J Hum Genet. 2002; 71:426-431. [PubMed: 12075506]

217. Ognibene A, Sabatelli P, Petrini S, Squarzoni S, Riccio M, Santi S, Villanova M, Palmeri S, Merlini L, Maraldi NM. Nuclear changes in a case of X-linked Emery-Dreifuss muscular dystrophy. Muscle Nerve. 1999; 22:864-869. [PubMed: 10398203]

218. Ohanian V, Gratzer W. Preparation of red-cell-membrane cytoskeletal constituents and characterisation of protein 4.1. Eur J Biochem. 1984; 144:375-379. [PubMed: 6541575]

219. Ohanian V, Wolfe LC, John KM, Pinder JC, Lux SE, Gratzer WB. Analysis of the ternary interaction of the red cell membrane skeletal proteins spectrin, actin, and 4.1. Biochemistry. 1984; 23:4416-4420. [PubMed: 6487610]

220. Olins AL, Rhodes G, Welch DB, Zwerger M, Olins DE. Lamin B receptor: Multi-tasking at the nuclear envelope. Nucleus. 2010; 1:53-70. [PubMed: 21327105]

221. Olsen JV, Blagoev B, Gnad F, Macek B, Kumar C, Mortensen P, Mann M. Global, in vivo, and site-specific phosphorylation dynamics in signaling networks. Cell. 2006; 127:635-648. [PubMed: 17081983]

222. Olsen JV, Vermeulen M, Santamaria A, Kumar C, Miller ML, Jensen LJ, Gnad F, Cox J, Jensen TS, Nigg EA, Brunak S, Mann M. Quantitative phosphoproteomics reveals widespread full phosphorylation site occupancy during mitosis. Sci Signal. 2010; 3:ra3. [PubMed: 20068231]

223. Ooshio T, Irie K, Morimoto K, Fukuhara A, Imai T, Takai Y. Involvement of LMO7 in the association of two cell-cell adhesion molecules, nectin and E-cadherin, through afadin and alphaactinin in epithelial cells. J Biol Chem. 2004; 279:31365-31373. [PubMed: 15140894]

224. Oosterwijk JC, Mansour S, van Noort G, Waterham HR, Hall CM, Hennekam RC. Congenital abnormalities reported in Pelger-Huet homozygosity as compared to Greenberg/HEM dysplasia: Highly variable expression of allelic phenotypes. J Med Genet. 2003; 40:937-941. [PubMed: 14684694]

225. Osada S, Ohmori SY, Taira M. XMAN1, an inner nuclear membrane protein, antagonizes BMP signaling by interacting with Smad1 in Xenopus embryos. Development. 2003; 130:1783-1794. [PubMed: 12642484]

226. Ostlund CEJ, Hallberg E, Lippincott-Schwartz J, Worman HJ. Intra-cellular trafficking of emerin, the Emery-Dreifuss muscular dystrophy protein. J Cell Sci. 1999; 112:1709-1719. [PubMed: 10318763]

227. Ostlund C, Sullivan T, Stewart CL, Worman HJ. Dependence of diffusional mobility of integral inner nuclear membrane proteins on A-type lamins. Biochemistry. 2006; 45:1374-1382. [PubMed: 16445279]

228. Otto A, Schmidt C, Luke G, Allen S, Valasek P, Muntoni F, Lawrence-Watt D, Patel K. Canonical Wnt signalling induces satellite-cell proliferation during adult skeletal muscle regeneration. J Cell Sci. 2008; 121:2939-2950. [PubMed: 18697834] 
229. Ozawa R, Hayashi YK, Ogawa M, Kurokawa R, Matsumoto H, Noguchi S, Nonaka I, Nishino I. Emerin-lacking mice show minimal motor and cardiac dysfunctions with nuclear-associated vacuoles. Am J Pathol. 2006; 168:907-917. [PubMed: 16507906]

230. Ozelius LJ, Hewett JW, Page CE, Bressman SB, Kramer PL, Shalish C, de Leon D, Brin MF, Raymond D, Corey DP, Fahn S, Risch NJ, Buckler AJ, Gusella JF, Breakefield XO. The earlyonset torsion dystonia gene (DYT1) encodes an ATP-binding protein. Nat Genet. 1997; 17:4048. [PubMed: 9288096]

231. Padiath QS, Saigoh K, Schiffmann R, Asahara H, Yamada T, Koeppen A, Hogan K, Ptacek LJ, Fu YH. Lamin B1 duplications cause autosomal dominant leukodystrophy. Nat Genet. 2006; 38:1114-1123. [PubMed: 16951681]

232. Padmakumar VC, Libotte T, Lu W, Zaim H, Abraham S, Noegel AA, Gotzmann J, Foisner R, Karakesisoglou I. The inner nuclear membrane protein Sun1 mediates the anchorage of Nesprin-2 to the nuclear envelope. J Cell Sci. 2005; 118:3419-3430. [PubMed: 16079285]

233. Pan C, Olsen JV, Daub H, Mann M. Global effects of kinase inhibitors on signaling networks revealed by quantitative phosphoproteomics. Mol Cell Proteomics. 2009; 8:2796-2808. [PubMed: 19651622]

234. Pan D, Estevez-Salmeron LD, Stroschein SL, Zhu X, He J, Zhou S, Luo K. The integral inner nuclear membrane protein MAN1 physically interacts with the R-Smad proteins to repress signaling by the transforming growth factor-\{beta\} superfamily of cytokines. J Biol Chem. 2005; 280:15992-16001. [PubMed: 15647271]

235. Parfenov VN, Davis DS, Pochukalina GN, Sample CE, Bugaeva EA, Murti KG. Nuclear actin filaments and their topological changes in frog oocytes. Exp Cell Res. 1995; 217:385-394. [PubMed: 7698240]

236. Pederson T, Aebi U. Actin in the nucleus: What form and what for? J Struct Biol. 2002; 140:3-9. [PubMed: 12490148]

237. Peric-Hupkes D, Meuleman W, Pagie L, Bruggeman SW, Solovei I, Brugman W, Graf S, Flicek P, Kerkhoven RM, van Lohuizen M, Reinders M, Wessels L, van Steensel B. Molecular maps of the reorganization of genome-nuclear lamina interactions during differentiation. Mol Cell. 2010; 38:603-613. [PubMed: 20513434]

238. Pickersgill H, Kalverda B, de Wit E, Talhout W, Fornerod M, van Steensel B. Characterization of the Drosophila melanogaster genome at the nuclear lamina. Nat Genet. 2006; 38:1005-1014. [PubMed: 16878134]

239. Pinder JC, Ohanian V, Gratzer WB. Spectrin and protein 4.1 as an actin filament capping complex. FEBS Lett. 1984; 169:161-164. [PubMed: 6538852]

240. Pinheiro I, Margueron R, Shukeir N, Eisold M, Fritzsch C, Richter FM, Mittler G, Genoud C, Goyama S, Kurokawa M, Son J, Reinberg D, Lachner M, Jenuwein T. Prdm3 and Prdm16 are H3K9me1 methyl-transferases required for mammalian heterochromatin integrity. Cell. 2012; 150:948-960. [PubMed: 22939622]

241. Polesskaya A, Seale P, Rudnicki MA. Wnt signaling induces the myogenic specification of resident CD45+ adult stem cells during muscle regeneration. Cell. 2003; 113:841-852. [PubMed: 12837243]

242. Prokocimer M, Davidovich M, Nissim-Rafinia M, Wiesel-Motiuk N, Bar DZ, Barkan R, Meshorer E, Gruenbaum Y. Nuclear lamins: Key regulators of nuclear structure and activities. J Cell Mol Med. 2009; 13:1059-1085. [PubMed: 19210577]

243. Puckelwartz M, McNally EM. Emery-Dreifuss muscular dystrophy. Handb Clin Neurol. 2011; 101:155-166. [PubMed: 21496632]

244. Puckelwartz MJ, Depreux FF, McNally EM. Gene expression, chromosome position and lamin A/C mutations. Nucleus. 2011; 2:162-167. [PubMed: 21818408]

245. Puente XS, Quesada V, Osorio FG, Cabanillas R, Cadinanos J, Fraile JM, Ordonez GR, Puente DA, Gutierrez-Fernandez A, Fanjul-Fernandez M, Levy N, Freije JM, Lopez-Otin C. Exome sequencing and functional analysis identifies BANF1 mutation as the cause of a hereditary progeroid syndrome. Am J Hum Genet. 2011; 88:650-656. [PubMed: 21549337] 
246. Putilina T, Jaworski C, Gentleman S, McDonald B, Kadiri M, Wong P. Analysis of a human cDNA containing a tissue-specific alternatively spliced LIM domain. Biochem Biophys Res Commun. 1998; 252:433-439. [PubMed: 9826547]

247. Raffaele Di Barletta M, Ricci E, Galluzzi G, Tonali P, Mora M, Morandi L, Romorini A, Voit T, Orstavik KH, Merlini L, Trevisan C, Biancalana V, Housmanowa-Petrusewicz I, Bione S, Ricotti R, Schwartz K, Bonne G, Toniolo D. Different mutations in the LMNA gene cause autosomal dominant and autosomal recessive Emery-Dreifuss muscular dystrophy. Am J Hum Genet. 2000; 66:1407-1412. [PubMed: 10739764]

248. Rajgor D, Shanahan CM. Nesprins: From the nuclear envelope and beyond. Expert Rev Mol Med. 2013; 15:e5. [PubMed: 23830188]

249. Raju GP, Dimova N, Klein PS, Huang HC. SANE, a novel LEM domain protein, regulates BMP signaling through interaction with Smad1. J Biol Chem. 2003; 278:428-437. [PubMed: 12393873]

250. Ranuncolo SM, Ghosh S, Hanover JA, Hart GW, Lewis BA. Evidence of the involvement of OGlcNAc-modified human RNA polymerase II CTD in transcription in vitro and in vivo. J Biol Chem. 2012; 287:23549-23561. [PubMed: 22605332]

251. Rashmi RN, Eckes B, Glockner G, Groth M, Neumann S, Gloy J, Sellin L, Walz G, Schneider M, Karakesisoglou I, Eichinger L, Noegel AA. The nuclear envelope protein Nesprin-2 has roles in cell proliferation and differentiation during wound healing. Nucleus. 2012; 3:172-186. [PubMed: 22198684]

252. Reddy KL, Zullo JM, Bertolino E, Singh H. Transcriptional repression mediated by repositioning of genes to the nuclear lamina. Nature. 2008; 452:243-247. [PubMed: 18272965]

253. Renard D, Fourcade G, Milhaud D, Bessis D, Esteves-Vieira V, Boyer A, Roll P, Bourgeois P, Levy N, De Sandre-Giovannoli A. Novel LMNA mutation in atypical Werner syndrome presenting with ischemic disease. Stroke. 2009; 40:e11-14. [PubMed: 19095983]

254. Renert AF, Leprince P, Dieu M, Renaut J, Raes M, Bours V, Chapelle JP, Piette J, Merville MP, Fillet M. The proapoptotic C16-ceramide-dependent pathway requires the death-promoting factor Btf in colon adenocarcinoma cells. J Proteome Res. 2009; 8:4810-4822. [PubMed: 19705920]

255. Renou L, Stora S, Yaou RB, Volk M, Sinkovec M, Demay L, Richard P, Peterlin B, Bonne G. Heart-hand syndrome of Slovenian type: A new kind of laminopathy. J Med Genet. 2008; 45:666-671. [PubMed: 18611980]

256. Ridgeway AG, Petropoulos H, Wilton S, Skerjanc IS. Wnt signaling regulates the function of MyoD and myogenin. J Biol Chem. 2000; 275:32398-32405. [PubMed: 10915791]

257. Rigbolt KT, Prokhorova TA, Akimov V, Henningsen J, Johansen PT, Kratchmarova I, Kassem M, Mann M, Olsen JV, Blagoev B. Systemwide temporal characterization of the proteome and phosphoproteome of human embryonic stem cell differentiation. Sci Signal. 2011; 4:rs3. [PubMed: 21406692]

258. Roberts RC, Sutherland-Smith AJ, Wheeler MA, Jensen ON, Emerson LJ, Spiliotis II, Tate CG, Kendrick-Jones J, Ellis JA. The Emery-Dreifuss muscular dystrophy associated-protein emerin is phosphorylated on serine 49 by protein kinase A. Febs J. 2006; 273:4562-4575. [PubMed: 16972941]

259. Rowat AC, Lammerding J, Ipsen JH. Mechanical properties of the cell nucleus and the effect of emerin deficiency. Biophys J. 2006; 91:4649-4664. [PubMed: 16997877]

260. Rozenblum E, Vahteristo P, Sandberg T, Bergthorsson JT, Syrjakoski K, Weaver D, Haraldsson K, Johannsdottir HK, Vehmanen P, Nigam S, Golberger N, Robbins C, Pak E, Dutra A, Gillander E, Stephan DA, Bailey-Wilson J, Juo SH, Kainu T, Arason A, Barkardottir RB, Nevanlinna H, Borg A, Kallioniemi OP. A genomic map of a 6-Mb region at 13q21-q22 implicated in cancer development: Identification and characterization of candidate genes. Hum Genet. 2002; 110:111121. [PubMed: 11935316]

261. Rush J, Moritz A, Lee KA, Guo A, Goss VL, Spek EJ, Zhang H, Zha XM, Polakiewicz RD, Comb MJ. Immunoaffinity profiling of tyrosine phosphorylation in cancer cells. Nat Biotechnol. 2005; 23:94-101. [PubMed: 15592455]

262. Saitoh N, Spahr CS, Patterson SD, Bubulya P, Neuwald AF, Spector DL. Proteomic analysis of interchromatin granule clusters. Mol Biol Cell. 2004; 15:3876-3890. [PubMed: 15169873] 
263. Sakabe K, Wang Z, Hart GW. Beta-N-acetylglucosamine (O-GlcNAc) is part of the histone code. Proc Natl Acad Sci U S A. 2010; 107:19915-19920. [PubMed: 21045127]

264. Sakaki M, Koike H, Takahashi N, Sasagawa N, Tomioka S, Arahata K, Ishiura S. Interaction between emerin and nuclear lamins. J Biochem (Tokyo). 2001; 129:321-327. [PubMed: 11173535]

265. Samwer M, Dehne HJ, Spira F, Kollmar M, Gerlich DW, Urlaub H, Gorlich D. The nuclear Factin interactome of Xenopus oocytes reveals an actin-bundling kinesin that is essential for meiotic cytokinesis. EMBO J. 2013; 32:1886-1902. [PubMed: 23727888]

266. Sarras H, Alizadeh Azami S, McPherson JP. In search of a function for BCLAF1. ScientificWorldJournal. 2010; 10:1450-1461. [PubMed: 20661537]

267. Scaffidi P, Misteli T. Lamin A-dependent misregulation of adult stem cells associated with accelerated ageing. Nat Cell Biol. 2008; 10:452-459. [PubMed: 18311132]

268. Scaffidi P, Misteli T. Lamin A-dependent nuclear defects in human aging. Science. 2006; 312:1059-1063. [PubMed: 16645051]

269. Schirmer EC, Florens L, Guan T, Yates JR III, Gerace L. Nuclear membrane proteins with potential disease links found by subtractive proteomics. Science. 2003; 301:1380-1382. [PubMed: 12958361]

270. Schirmer EC, Guan T, Gerace L. Involvement of the lamin rod domain in heterotypic lamin interactions important for nuclear organization. J Cell Biol. 2001; 153:479-489. [PubMed: 11331300]

271. Schmidt HH, Genschel J, Baier P, Schmidt M, Ockenga J, Tietge UJ, Propsting M, Buttner C, Manns MP, Lochs H, Brabant G. Dyslipemia in familial partial lipodystrophy caused by an R482W mutation in the LMNA gene. J Clin Endocrinol Metab. 2001; 86:2289-2295. [PubMed: 11344241]

272. Schneider M, Lu W, Neumann S, Brachner A, Gotzmann J, Noegel AA, Karakesisoglou I. Molecular mechanisms of centrosome and cytoskele-ton anchorage at the nuclear envelope. Cell Mol Life Sci. 2011; 68:1593-1610. [PubMed: 20922455]

273. Schuster J, Sundblom J, Thuresson AC, Hassin-Baer S, Klopstock T, Dichgans M, Cohen OS, Raininko R, Melberg A, Dahl N. Genomic duplications mediate overexpression of lamin B1 in adult-onset auto-somal dominant leukodystrophy (ADLD) with autonomic symptoms. Neurogenetics. 2011; 12:65-72. [PubMed: 21225301]

274. Segura-Totten M, Kowalski AM, Craigie R, Wilson KL. Barrier-to-autointegration factor: Major roles in chromatin decondensation and nuclear assembly. J Cell Biol. 2002; 158:475-485. [PubMed: 12163470]

275. Segura-Totten M, Wilson K. BAF: Roles in chromatin, nuclear structure and retrovirus integration. Trends Cell Biol. 2004; 14:261-266. [PubMed: 15130582]

276. Semenova E, Wang X, Jablonski MM, Levorse J, Tilghman SM. An engineered 800 kilobase deletion of Uchl3 and $\mathrm{Lmo} 7$ on mouse chromosome 14 causes defects in viability, postnatal growth and degeneration of muscle and retina. Hum Mol Genet. 2003; 12:1301-1312. [PubMed: 12761045]

277. Sewry CA, Brown SC, Mercuri E, Bonne G, Feng L, Camici G, Morris GE, Muntoni F. Skeletal muscle pathology in autosomal dominant Emery-Dreifuss muscular dystrophy with lamin A/C mutations. Neuropathol Appl Neurobiol. 2001; 27:281-290. [PubMed: 11532159]

278. Shackleton S, Lloyd DJ, Jackson SN, Evans R, Niermeijer MF, Singh BM, Schmidt H, Brabant G, Kumar S, Durrington PN, Gregory S, O'Rahilly S, Trembath RC. LMNA, encoding lamin A/C, is mutated in partial lipodystrophy [see comments]. Nat Genet. 2000; 24:153-156. [PubMed: 10655060]

279. Shen JJ, Brown CA, Lupski JR, Potocki L. Mandibuloacral dysplasia caused by homozygosity for the R527H mutation in lamin A/C. J Med Genet. 2003; 40:854-857. [PubMed: 14627682]

280. Shevelyov YY, Nurminsky DI. The nuclear lamina as a gene-silencing hub. Curr Issues Mol Biol. 2012; 14:27-38. [PubMed: 21795760]

281. Shimi T, Butin-Israeli V, Adam SA, Goldman RD. Nuclear lamins in cell regulation and disease. Cold Spring Harb Symp Quant Biol. 2010; 75:525-531. [PubMed: 21467145] 
282. Shimi T, Butin-Israeli V, Goldman RD. The functions of the nuclear envelope in mediating the molecular crosstalk between the nucleus and the cytoplasm. Curr Opin Cell Biol. 2012; 24:7178. [PubMed: 22192274]

283. Shumaker DK, Solimando L, Sengupta K, Shimi T, Adam SA, Grunwald A, Strelkov SV, Aebi U, Cardoso MC, Goldman RD. The highly conserved nuclear lamin Ig-fold binds to PCNA: Its role in DNA replication. J Cell Biol. 2008; 181:269-280. [PubMed: 18426975]

284. Simha V, Agarwal AK, Oral EA, Fryns JP, Garg A. Genetic and phenotypic heterogeneity in patients with mandibuloacral dysplasia-associated lipodystrophy. J Clin Endocrinol Metab. 2003; 88:2821-2824. [PubMed: 12788894]

285. Simon DN, Wilson KL. The nucleoskeleton as a genome-associated dynamic 'network of networks'. Nat Rev Mol Cell Biol. 2011; 12:695-708. [PubMed: 21971041]

286. Simon DN, Zastrow MS, Wilson KL. Direct actin binding to A- and B-type lamin tails and actin filament bundling by the lamin A tail. Nucleus. 2010; 1:264-272. [PubMed: 21327074]

287. Sinkovec M, Petrovic D, Volk M, Peterlin B. Familial progressive sinoatrial and atrioventricular conduction disease of adult onset with sudden death, dilated cardiomyopathy, and brachydactyly. A new type of heart-hand syndrome? Clin Genet. 2005; 68:155-160. [PubMed: 15996213]

288. Skoko D, Li M, Huang Y, Mizuuchi M, Cai M, Bradley CM, Pease PJ, Xiao B, Marko JF, Craigie R, Mizuuchi K. Barrier-to-autointegration factor (BAF) condenses DNA by looping. Proc Natl Acad Sci U S A. 2009; 106:16610-16615. [PubMed: 19805345]

289. Smigiel R, Jakubiak A, Esteves-Vieira V, Szela K, Halon A, Jurek T, Levy N, De SandreGiovannoli A. Novel frameshifting mutations of the ZMPSTE24 gene in two siblings affected with restrictive dermopathy and review of the mutations described in the literature. Am J Med Genet A. 2010; 152A:447-452. [PubMed: 20101687]

290. Smitt JH, van Asperen CJ, Niessen CM, Beemer FA, van Essen AJ, Hulsmans RF, Oranje AP, Steijlen PM, Wesbyvan Swaay E, Tamminga P, Breslau-Siderius EJ. Restrictive dermopathy. Report of 12 cases. Dutch Task Force on Genodermatology. Arch Dermatol. 1998; 134:577-579. [PubMed: 9606327]

291. Somech R, Shaklai S, Geller O, Amariglio N, Simon AJ, Rechavi G, Gal-Yam EN. The nuclearenvelope protein and transcriptional repressor LAP2beta interacts with HDAC3 at the nuclear periphery, and induces histone H4 deacetylation. J Cell Sci. 2005; 118:4017-4025. [PubMed: 16129885]

292. Speckman RA, Garg A, Du F, Bennett L, Veile R, Arioglu E, Taylor SI, Lovett M, Bowcock AM. Mutational and haplotype analyses of families with familial partial lipodystrophy (Dunnigan variety) reveal recurrent missense mutations in the globular C-terminal domain of lamin A/C. Am J Hum Genet. 2000; 66:1192-1198. [PubMed: 10739751]

293. Sui S, Wang J, Yang B, Song L, Zhang J, Chen M, Liu J, Lu Z, Cai Y, Chen S, Bi W, Zhu Y, He F, Qian X. Phosphoproteome analysis of the human Chang liver cells using SCX and a complementary mass spectrometric strategy. Proteomics. 2008; 8:2024-2034. [PubMed: 18491316]

294. Sullivan T, Escalante-Alcalde D, Bhatt H, Anver M, Bhat N, Nagashima K, Stewart CL, Burke B. Loss of A-type lamin expression compromises nuclear envelope integrity leading to muscular dystrophy. J Cell Biol. 1999; 147:913-920. [PubMed: 10579712]

295. Tao WA, Wollscheid B, O’Brien R, Eng JK, Li XJ, Bodenmiller B, Watts JD, Hood L, Aebersold R. Quantitative phosphoproteome analysis using a dendrimer conjugation chemistry and tandem mass spectrometry. Nat Methods. 2005; 2:591-598. [PubMed: 16094384]

296. Tazir M, Azzedine H, Assami S, Sindou P, Nouioua S, Zemmouri R, Hamadouche T, Chaouch M, Feingold J, Vallat JM, Leguern E, Grid D. Phenotypic variability in autosomal recessive axonal Charcot-Marie-Tooth disease due to the R298C mutation in lamin A/C. Brain. 2004; 127:154163. [PubMed: 14607793]

297. Tifft KE, Bradbury KA, Wilson KL. Tyrosine phosphorylation of nuclear-membrane protein emerin by Src, Abl and other kinases. J Cell Sci. 2009; 122:3780-3790. [PubMed: 19789182]

298. Tilgner K, Wojciechowicz K, Jahoda C, Hutchison C, Markiewicz E. Dynamic complexes of Atype lamins and emerin influence adipogenic capacity of the cell via nucleocytoplasmic distribution of beta-catenin. J Cell Sci. 2009; 122:401-413. [PubMed: 19126678] 
299. Towbin BD, Gonzalez-Aguilera C, Sack R, Gaidatzis D, Kalck V, Meister P, Askjaer P, Gasser SM. Step-wise methylation of histone H3K9 positions heterochromatin at the nuclear periphery. Cell. 2012; 150:934-947. [PubMed: 22939621]

300. Tsai CF, Wang YT, Chen YR, Lai CY, Lin PY, Pan KT, Chen JY, Khoo KH, Chen YJ. Immobilized metal affinity chromatography revisited: $\mathrm{pH} /$ acid control toward high selectivity in phosphoproteomics. J Proteome Res. 2008; 7:4058-4069. [PubMed: 18707149]

301. Tsuchiya Y, Hase A, Ogawa M, Yorifuji H, Arahata K. Distinct regions specify the nuclear membrane targeting of emerin, the responsible protein for Emery-Dreifuss muscular dystrophy. Eur J Biochem. 1999; 259:859-865. [PubMed: 10092874]

302. Tunnah D, Sewry CA, Vaux D, Schirmer EC, Morris GE. The apparent absence of lamin B1 and emerin in many tissue nuclei is due to epitope masking. J Mol Histol. 2005; 36:337-344. [PubMed: 16283426]

303. Vadrot N, Duband-Goulet I, Cabet E, Attanda W, Barateau A, Vicart P, Gerbal F, Briand N, Vigouroux C, Oldenburg AR, Lund EG, Collas P, Buendia B. The p.R482W substitution in Atype lamins deregulates SREBP1 activity in Dunnigan-type familial partial lipodystrophy. Hum Mol Genet. 2015; 24:2096-2109. [PubMed: 25524705]

304. van der Kooi AJ, Barth PG, Busch HF, de Haan R, Ginjaar HB, van Essen AJ, van Hooff LJ, Howeler CJ, Jennekens FG, Jongen P, Oosterhuis HJ, Padberg GW, Spaans F, Wintzen AR, Wokke JH, Bakker E, van Ommen GJ, Bolhuis PA, de Visser M. The clinical spectrum of limb girdle muscular dystrophy. A survey in The Netherlands. Brain. 1996; 119(Pt 5):1471-1480. [PubMed: 8931572]

305. van der Kooi AJ, Ledderhof TM, de Voogt WG, Res CJ, Bouwsma G, Troost D, Busch HF, Becker AE, de Visser M. A newly recognized autosomal dominant limb girdle muscular dystrophy with cardiac involvement. Ann Neurol. 1996; 39:636-642. [PubMed: 8619549]

306. van Engelen BG, Muchir A, Hutchison CJ, van der Kooi AJ, Bonne G, Lammens M. The lethal phenotype of a homozygous nonsense mutation in the lamin A/C gene. Neurology. 2005; 64:374-376. [PubMed: 15668447]

307. Vander Heyden AB, Naismith TV, Snapp EL, Hodzic D, Hanson PI. LULL1 retargets TorsinA to the nuclear envelope revealing an activity that is impaired by the DYT1 dystonia mutation. Mol Biol Cell. 2009; 20:2661-2672. [PubMed: 19339278]

308. Vigouroux C, Auclair M, Dubosclard E, Pouchelet M, Capeau J, Courvalin JC, Buendia B. Nuclear envelope disorganization in fibroblasts from lipodystrophic patients with heterozygous R482Q/W mutations in the lamin A/C gene. J Cell Sci. 2001; 114:4459-4468. [PubMed: 11792811]

309. Vlcek S, Foisner R. Lamins and lamin-associated proteins in aging and disease. Curr Opin Cell Biol. 2007; 19:298-304. [PubMed: 17466505]

310. Vytopil M, Benedetti S, Ricci E, Galluzzi G, Dello Russo A, Merlini L, Boriani G, Gallina M, Morandi L, Politano L, Moggio M, Chiveri L, Hausmanova-Petrusewicz I, Ricotti R, Vohanka S, Toman J, Toniolo D. Mutation analysis of the lamin A/C gene (LMNA) among patients with different cardiomuscular phenotypes. J Med Genet. 2003; 40:e132. [PubMed: 14684700]

311. Wang X, Xu S, Rivolta C, Li LY, Peng GH, Swain PK, Sung CH, Swaroop A, Berson EL, Dryja TP, Chen S. Barrier to autointegration factor interacts with the cone-rod homeobox and represses its transactivation function. J Biol Chem. 2002; 277:43288-43300. [PubMed: 12215455]

312. Warren DT, Tajsic T, Mellad JA, Searles R, Zhang Q, Shanahan CM. Novel nuclear nesprin-2 variants tether active extracellular signal-regulated MAPK1 and MAPK2 at promyelocytic leukemia protein nuclear bodies and act to regulate smooth muscle cell proliferation. J Biol Chem. 2010; 285:1311-1320. [PubMed: 19861416]

313. Warren DT, Zhang Q, Weissberg PL, Shanahan CM. Nesprins: Intra-cellular scaffolds that maintain cell architecture and coordinate cell function? Expert Rev Mol Med. 2005; 7:1-15.

314. Waterham HR, Koster J, Mooyer P, Noort Gv G, Kelley RI, Wilcox WR, Wanders RJ, Hennekam RC, Oosterwijk JC. Autosomal recessive HEM/Greenberg skeletal dysplasia is caused by 3 betahydroxysterol delta 14-reductase deficiency due to mutations in the lamin B receptor gene. Am J Hum Genet. 2003; 72:1013-1017. [PubMed: 12618959] 
315. Wheeler MA, Warley A, Roberts RG, Ehler E, Ellis JA. Identification of an emerin-beta-catenin complex in the heart important for intercalated disc architecture and beta-catenin localisation. Cell Mol Life Sci. 2010; 67:781-796. [PubMed: 19997769]

316. Wiesel N, Mattout A, Melcer S, Melamed-Book N, Herrmann H, Medalia O, Aebi U, Gruenbaum Y. Laminopathic mutations interfere with the assembly, localization, and dynamics of nuclear lamins. Proc Natl Acad Sci U S A. 2008; 105:180-185. [PubMed: 18162544]

317. Wilkie GS, Korfali N, Swanson SK, Malik P, Srsen V, Batrakou DG, de las Heras J, Zuleger N, Kerr AR, Florens L, Schirmer EC. Several novel nuclear envelope transmembrane proteins identified in skeletal muscle have cytoskeletal associations. Mol Cell Proteomics. 2011; 10:M110003129.

318. Wilkinson FL, Holaska JM, Zhang Z, Sharma A, Manilal S, Holt I, Stamm S, Wilson KL, Morris GE. Emerin interacts in vitro with the splicing-associated factor, YT521-B. Eur J Biochem. 2003; 270:2459-2466. [PubMed: 12755701]

319. Witt DR, Hayden MR, Holbrook KA, Dale BA, Baldwin VJ, Taylor GP. Restrictive dermopathy: A newly recognized autosomal recessive skin dysplasia. Am J Med Genet. 1986; 24:631-648. [PubMed: 2426945]

320. Wolff N, Gilquin B, Courchay K, Callebaut I, Worman HJ, Zinn-Justin S. Structural analysis of emerin, an inner nuclear membrane protein mutated in X-linked Emery-Dreifuss muscular dystrophy. FEBS Lett. 2001; 501:171-176. [PubMed: 11470279]

321. Worman HJ. Nuclear lamins and laminopathies. J Pathol. 2012; 226:316-325. [PubMed: 21953297]

322. Worman HJ, Fong LG, Muchir A, Young SG. Laminopathies and the long strange trip from basic cell biology to therapy. J Clin Invest. 2009; 119:1825-1836. [PubMed: 19587457]

323. Wozniak MA, Baker BM, Chen CS, Wilson KL. The emerin-binding transcription factor Lmo7 is regulated by association with p130Cas at focal adhesions. PeerJ. 2013; 1:e134. [PubMed: 24010014]

324. Yates JR, Bagshaw J, Aksmanovic VM, Coomber E, McMahon R, Whittaker JL, Morrison PJ, Kendrick-Jones J, Ellis JA. Genotype-phenotype analysis in X-linked Emery-Dreifuss muscular dystrophy and identification of a missense mutation associated with a milder phenotype. Neuromuscul Disord. 1999; 9:159-165. [PubMed: 10382909]

325. Zachara NE, Hart GW. O-GlcNAc a sensor of cellular state: The role of nucleocytoplasmic glycosylation in modulating cellular function in response to nutrition and stress. Biochim Biophys Acta. 2004; 1673:13-28. [PubMed: 15238246]

326. Zachara NE, Molina H, Wong KY, Pandey A, Hart GW. The dynamic stress-induced "O-GlcNAcome" highlights functions for O-GlcNAc in regulating DNA damage/repair and other cellular pathways. Amino Acids. 2011; 40:793-808. [PubMed: 20676906]

327. Zhang Q, Bethmann C, Worth NF, Davies JD, Wasner C, Feuer A, Ragnauth CD, Yi Q, Mellad JA, Warren DT, Wheeler MA, Ellis JA, Skepper JN, Vorgerd M, Schlotter-Weigel B, Weissberg PL, Roberts RG, Wehnert M, Shanahan CM. Nesprin-1 and -2 are involved in the pathogenesis of Emery Dreifuss muscular dystrophy and are critical for nuclear envelope integrity. Hum Mol Genet. 2007; 16:2816-2833. [PubMed: 17761684]

328. Zhang Q, Ragnauth C, Greener MJ, Shanahan CM, Roberts RG. The nesprins are giant actinbinding proteins, orthologous to Drosophila melanogaster muscle protein MSP-300. Genomics. 2002; 80:473-481. [PubMed: 12408964]

329. Zhang X, Lei K, Yuan X, Wu X, Zhuang Y, Xu T, Xu R, Han M. SUN1/2 and Syne/Nesprin-1/2 complexes connect centrosome to the nucleus during neurogenesis and neuronal migration in mice. Neuron. 2009; 64:173-187. [PubMed: 19874786]

330. Zhang X, Xu R, Zhu B, Yang X, Ding X, Duan S, Xu T, Zhuang Y, Han M. Syne-1 and Syne-2 play crucial roles in myonuclear anchorage and motor neuron innervation. Development. 2007; 134:901-908. [PubMed: 17267447]

331. Zhen YY, Libotte T, Munck M, Noegel AA, Korenbaum E. NUANCE, a giant protein connecting the nucleus and actin cytoskeleton. J Cell Sci. 2002; 115:3207-3222. [PubMed: 12118075]

332. Zuleger N, Boyle S, Kelly DA, de las Heras JI, Lazou V, Korfali N, Batrakou DG, Randles KN, Morris GE, Harrison DJ, Bickmore WA, Schirmer EC. Specific nuclear envelope transmembrane 
proteins can promote the location of chromosomes to and from the nuclear periphery. Genome Biol. 2013; 14:R14. [PubMed: 23414781]

333. Zullo JM, Demarco IA, Pique-Regi R, Gaffney DJ, Epstein CB, Spooner CJ, Luperchio TR, Bernstein BE, Pritchard JK, Reddy KL, Singh H. DNA sequence-dependent

compartmentalization and silencing of chromatin at the nuclear lamina. Cell. 2012; 149:14741487. [PubMed: 22726435]

334. Zuo B, Yang J, Wang F, Wang L, Yin Y, Dan J, Liu N, Liu L. Influences of lamin A levels on induction of pluripotent stem cells. Biol Open. 2012; 1:1118-1127. [PubMed: 23213392] 


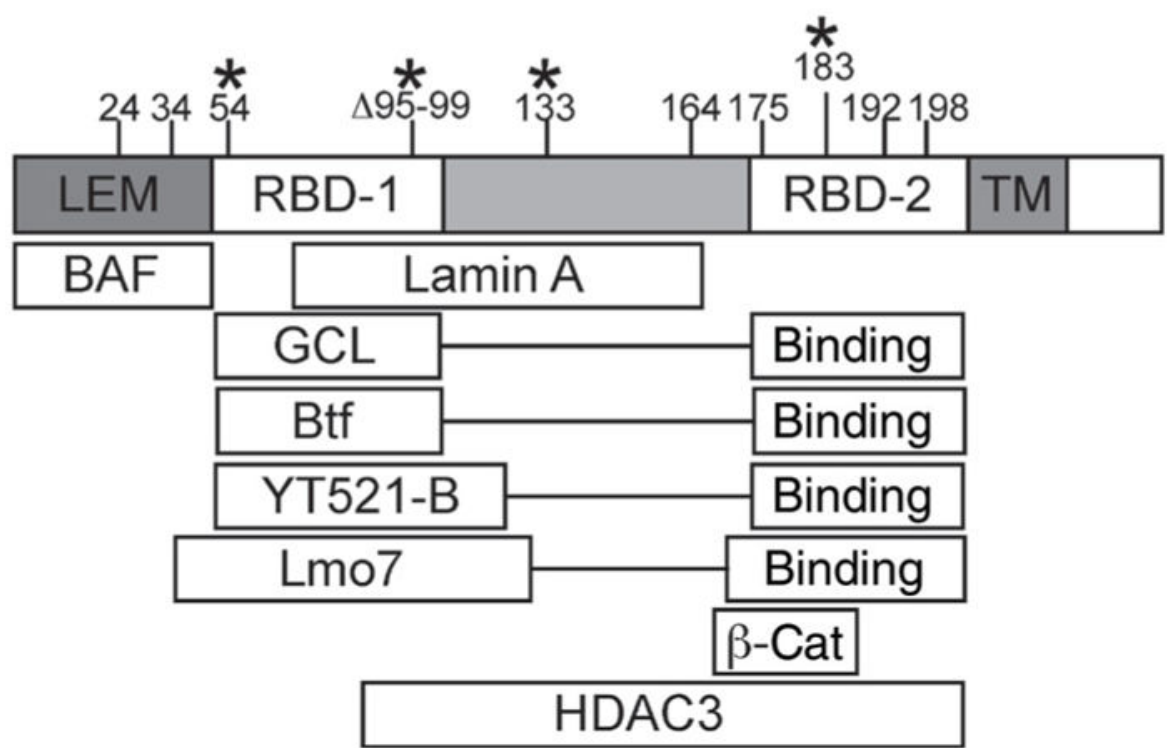

Figure 1.

Map of emerin domain structure. Emerin regions that bind each emerin-binding protein are shown below the emerin domain structure. Mutations in the residues shown block binding to one or more partners and define domain boundaries. Asterisks indicate positions of EDMDdisease-causing mutations. TM, transmembrane domain; RBD, repressor-binding domain. 


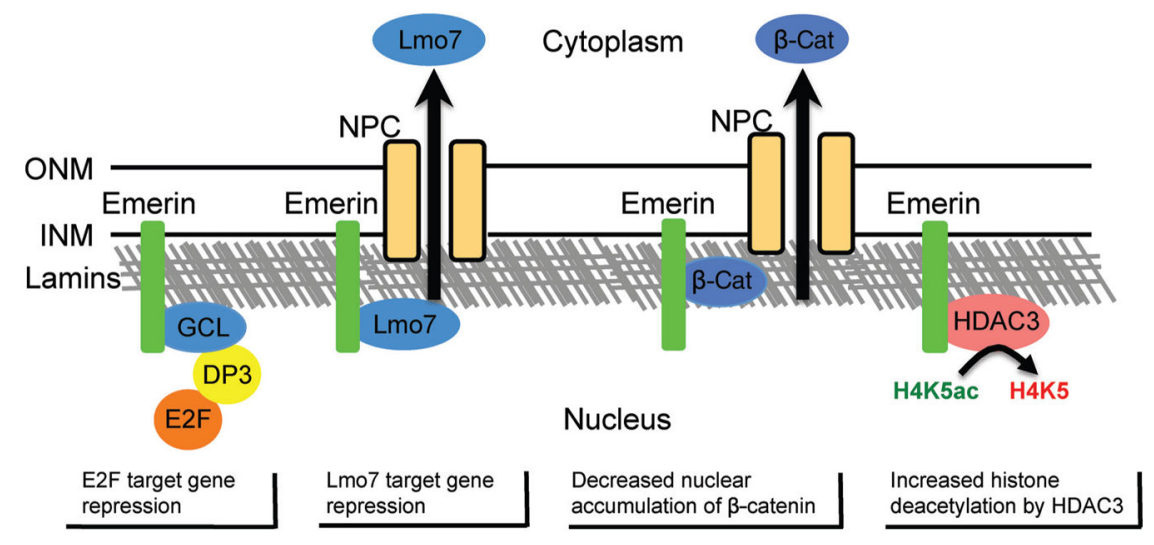

Figure 2.

Emerin regulates gene expression using multiple mechanisms. Emerin regulates transcription regulators, including GCL and Lmo7, by sequestering them at the nuclear envelope to inhibit their activity. Additionally, emerin binding to transcription regulators also can effect their nuclear localization, including Lmo7 and $\beta$-catenin, to inhibit activation of their target genes. Emerin also activates HDAC3 activity at the nuclear envelope to inhibit transcription of genes at the nuclear envelope. 


\section{Table 1}

Diseases Caused by Mutations in Genes Encoding Nuclear Envelope Proteins

\begin{tabular}{|c|c|c|}
\hline & Gene mutated & Affected tissues \\
\hline \multicolumn{3}{|l|}{ Striated muscle diseases } \\
\hline Emery-Dreifuss muscular dystrophy & $\begin{array}{l}\text { LMNA, EMD, SYNE1, SYNE2, } \\
T M E M 43, T M P O\end{array}$ & Skeletal muscle, tendons, heart \\
\hline Limb-girdle muscular dystrophy & $L M N A, E M D$ & Skeletal muscle, heart, tendons \\
\hline Dilated cardiomyopathy & $\begin{array}{l}\text { LMNA, EMD, SYNE1, SYNE2, } \\
T M E M 43, T M P O\end{array}$ & Heart \\
\hline Congenital muscular dystrophy & $L M N A$ & Skeletal muscle, heart \\
\hline Heart-hand syndrome & $L M N A$ & Heart, phalanges of hands and feet \\
\hline \multicolumn{3}{|l|}{ Lipodystrophy syndromes } \\
\hline Dunnigan-type familial partial lipodystrophy & $L M N A$ & Adipose \\
\hline MAD & LMNA, ZMPSTE24 & Adipose, bone \\
\hline Acquired partial lipodystrophy & $L M N B 2$ & Adipose \\
\hline \multicolumn{3}{|l|}{ Accelerated aging disorders } \\
\hline Atypical Werner syndrome & $L M N A$ & Heart, skin, vasculature, muscle, bone, adipose \\
\hline HGPS & $L M N A$ & Tendons, vasculature, skin, heart, bone \\
\hline Restrictive dermopathy & LMNA, ZMPSTE24 & Bone, skin, tendons \\
\hline Atypical progeria syndrome & $B A N F 1$ & Skin, bone, adipose \\
\hline \multicolumn{3}{|l|}{ Peripheral nerve disorders } \\
\hline Charcot-Marie-Tooth disease & $L M N A$ & Axons \\
\hline Adult-onset leukodystrophy & $L M N B 1$ & Neurons of CNS \\
\hline Spinocerebellar ataxia type 8 & $S Y N E 1$ & Neurons of the cerebellum \\
\hline Torsion dystonia (DYT1) & $D Y T 1$ & Neurons of CNS \\
\hline \multicolumn{3}{|l|}{ Bone diseases } \\
\hline Buschke-Ollendorff syndrome & LEMD3 & Connective tissue, bone \\
\hline Osteopoikilosis & LEMD3 & Bone \\
\hline Greenberg skeletal dysplasia & $L B R$ & Bone \\
\hline \multicolumn{3}{|l|}{ Other } \\
\hline PHA & $L B R$ & Granulocytes \\
\hline
\end{tabular}


Table 2

Emerin-Binding Partners and Their Role in Cellular Function

\begin{tabular}{llll}
\hline Nuclear architecture & Chromatin dynamics & Transcription factor activity & Cell signaling \\
\hline Lamin A/C & NCoR complex & GCL & Rb \\
Lamin B & HDAC3 & Btf & Integrin signaling \\
Nesprins & BAF & Lmo7 & MAPK \\
SUN1/2 & & $\beta$-Catenin & NF-xB \\
Actin & & JNK \\
& & & ERK1/2 \\
& & & IGF \\
& & & NOTCH \\
& & & Wnt \\
& & TGF $\beta$ \\
\hline
\end{tabular}

